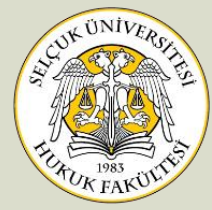

\title{
ROMA HUKUKUNDA ŞANTAJ
}

Dr. Öğr. Üyesi Buse AKSARAY ERKMAN*

Öz

Roma hukukunda suçlar, bireyin menfaatinin ya da kamu menfaatinin ihlaline bağlı olarak özel suçlar ve kamu suçları olarak ayrılmış, özel suçlar kişilerin uğradıkları zararın giderilmesini amaçlayan yaptırım türlerine bağlanmıştır. Hukuk tarihi bakımından kişinin kötü bir sonuç doğacağ 1 ve zarara uğrayacağ 1 yönünde inandırıcı şekilde tehdit edilerek, bunun önlenmesi için diğer tarafa para vermek zorunda bırakılması şeklinde tanımlanabilecek ve Roma hukukunda açıkça bir suç tipi olarak düzenlemeyen şantaj, ihlal edilen menfaate göre farklı hukuki niteliklere sahip olmaktadır. Fiilin kamu menfaatini ihlal etmesi, kamu suçu olarak kabul edilmesi sonucunu doğurmaktadır. Bu kapsamda leges repetundarum adlı kanunlarla getirilen yargılamaya ve cezalara ilişkin hükümler uygulanmıştır. Özel menfaatin ihlal edilmesi durumunda ise, kişiliğe verilen zarar (iniuria) veya korkutma (metus) niteliğindeki özel suçun oluştuğu kabul edilebilir.

\section{Anahtar Kelimeler}

Roma Hukuku • Kamu Suçları • Özel Suçlar • Şantaj • Leges Repetundarum

* $\quad$ Dr. Öğr. Üyesi, İstanbul Aydın Üniversitesi Hukuk Fakültesi Roma Hukuku Anabilim Dalı, İstanbul, Türkiye| Asst. Prof., İstanbul Aydın University, Faculty of Law, Department of Roman Law, İstanbul, Turkey.

$\Xi$ buseaksaray@aydin.edu.tr • ORCID 0000-0002-6606-9946

Atıf Şekli | Cite As: ERKMAN Buse AKSARAY, "Roma Hukukunda Şantaj", SüHFD., C. 29, S. 4, 2021, s. 2821-2859.

İntihal | Plagiarism: Bu makale intihal programında taranmış ve en az iki hakem incelemesinden geçmiştir. | This article has been scanned via a plagiarism software and reviewed by at least two referees. 


\title{
BLACKMAILING IN ROMAN LAW
}

\begin{abstract}
In Roman law, crimes were divided into private crimes and public crimes depending on the violation of private or public interest, andprivate crimes were linked to the types of sanctions aimed at eliminating the damage suffered by people. In terms of legal history, blackmailingthat has not regulated as a type of crime in Roman law, was defined as the one being threatened in a convincing way that a bad consequence and damage will occur, and forced to give money to the other party to prevent this, had different legal qualities according to the violation of the interest.The violation of the interest of the public resulted in it being considered a public crime. Provisions on trials and punishments were introduced by laws called leges repetundarum. In case of the violation of the interest of the individual, it might be considered that iniuria or metushad occurred.
\end{abstract}

\section{Key Words}

Roman Law $\bullet$ Crimen $\bullet$ Delict $\bullet$ Blackmail $\bullet$ Leges Repetundarum

\section{GİRIŞ}

Roma hukuku bakımından özel hukuk alanı gibi sistemli şekilde düzenlenmeyen ve gelişmeyen ceza hukuku alanı kapsamında, zedelenen menfaate göre suç ayrımı yapılmış ve ilk düzenlemelerle kişisel intikam duygusunu tatmin etmek, sonraki düzenlemelerle ise uğranılan zararı gidermek amacıyla yaptırımlar belirlenmiştir. Başlangıçta din kurallarından doğan, daha sonra zaman içinde devlet yapısının gelişmesi ile kamu düzeniyle ilişkilendirilen bazı fiillerin kamu menfaatine zarar verdiği kabul edildiğinden, bu şekilde ortaya çıkan suçlar kamu suçu olarak tanımlanmış, sayıları az olan bu suçların takibi devlet tarafından gerçekleştirilmiştir. Kişilerin özel menfaatlerini ihlal eden suçlar ise, özel suçlar olarak tanımlanmış, zarara uğrayan kişiler tarafından takip edilmiş ve aynı zamanda cezalandırmaya yönelik yaptırımlarla zarara uğrayanın zararının giderilmesi de amaçlanmıştır. Bu doğrultuda bu suçlar borç kaynağı olarak borçlar hukuku alanını ilgilendiren haksız fiil kavramının karşılığını da oluşturmaktadır ${ }^{1}$.

1 İPEK, Nurcan, Roma Hukukunda Gasp (Rapina), İstanbul, 2001 (Gasp), s. 23. 
Bu kavramlar doğrultusunda incelenmesi amaçlanan şantaj fiili, Roma Cumhuriyet Dönemi içinde toplumsal ve siyasal yapıda ortaya çıkan değişimlerin sonucu olarak yaygınlaşmıştır. Dolayısıyla kamu suçları kapsamında incelenmesi ancak bu dönemden sonraki dönemlerin hukuki düzenlemeleri doğrultusunda yapılabilir. Açıkça ayrı bir suç tipi olarak düzenlenmediği için, hukuka aykırı şekilde para ve mal alınması amacıyla gerçekleştirilen haraç kesme, hile yapma, rüşvet alma, irtikap, şantaj ve benzeri fiilleri kapsayan ve leges repetundarum olarak adlandırılan, temelde görevin kötüye kullanılmasını engellemek amacıyla çıkarılan kanunlar bu kapsamda incelenecektir. Kanunlar maddi hukuk kuralları yanında usul ve yargılamaya ilişkin detaylı düzenlemeler de içermektedir. İnceleme büyük oranda maddi hukuk kuralları çerçevesinde yapılmaya çalışılacak, usule ilişkin kurallara sınırlı oranda yer verilecektir.

Fiilin kamu suçu oluşturacak şekilde kamu menfaatini ihlal etmediği durumlarda ise, zarar görenin kişiliğine yönelik saldırı gerçekleşmesi veya korkutulması sonucu doğuyorsa özel suç işlendiği sonucuna ulaşılabilir. Bu kapsamda ise haksız fiil niteliğinde kabul edilen özel suçlardan kişiliğe verilen zarar (iniuria) ve korkutma (metus) kavramları incelenecektir. Bu incelemenin amacı iki hukuki kurumu bütünüyle ele almaktan ziyade, şantaj fiili ile bağdaştığı ölçüde kavramların genel nitelikleri ile sınırlandırılacaktır.

\section{ROMA HUKUKUNDA SUÇ KAVRAMI}

\section{A. Genel Olarak}

Roma hukukunda ceza hukuku alanı, özel hukuk alanı kadar kapsamlı ve erken gelişme göstermemiş, ceza hukukunun sistemli hale gelmesi ihtiyaçlarla bağlantılı olarak bu alandaki gelişmelerle zaman içinde gerçekleşmiştir. Roma ceza hukuku alanının varlığının bile tartışıldığı bu konuda ilk düzenlemeler kaynağını din kurallarından, örf ve âdet kurallarından ve bunlarla bağlantılı olacak şekilde aile babasının aile üzerindeki hak ve yetkilerinden almıştır².

2 AYİTER, Kudret, "Roma Ceza Hukukunda Quaestiones Perpetuae ve Cognitio Extra Ordinem", Ahmet Esat Arsebük'e Armağan, Ankara, 1958, s. 341-343; UÇARYILMAZ, Talya Şans/EMİROĞLU, Haluk, "Roma Hukukunda Haksız Fiil ve Suç İlişkisi Işı̆̆ında Tazminatın Cezalandırıcı Fonksiyonu”, Ankara Üniversitesi Hukuk Fakültesi Dergisi, Cilt: 69, Sayı: 2, 2020, s. 836, 839. 
Suç kavramı, On İki Levha Kanunu'nun içeriğinde yer alacak kadar eski zamanlardan itibaren iki gruba ayrılarak incelenmiş, suç ve haksız fiil kavramları arasında ayrım gözetilmemiştir. Suçların kapsamının çok dar olduğu ilk dönemlerde bütün haksız fiiller aynı zamanda suç sayılmıştır ve suçlar, kamu düzeninin ya da zarar görenin etkilenmesine bağlı olarak özel suçlar ve kamu suçları şeklinde ikiye ayrılmıştır$^{3}$. Suçu işleyenin cezalandırılmasının ise, adil olacağı gerekçesiyle suçtan zarar gören tarafından yapılması kabul edilmiştir ${ }^{4}$.

Delictum privatum veya delictum ${ }^{5}$ olarak adlandırılan ve Türk hukukunda haksız fiil olarak nitelendirilen özel suçlar, zarar gören tarafından takip edilen ve özel kişilerin menfaatlerini ihlal eden suçlardır ${ }^{6}$. Delictum publicum veya crimen olarak adlandırılan kamu suçları ise, gerçekleştirilen fiilin Roma halkına yönelik olduğu kabul edildiğindenkamu menfaatini ihlal eden, sınırlı sayıda belirlenen ve devlet tarafından takip edilip cezalandırılan suçlardır ${ }^{8}$ Özel suç sayılan fiillere ilişkin yaptırımlarla bireyin şahsına ya da malına verilen zararların giderilmesi amaçla-

3 RADO, Türkan, Roma Hukuku Dersleri Borçlar Hukuku, İstanbul, 2016(Borçlar), s. 141; KARADENIZ ÇELEBİCAN, Özcan, Roma Hukuku, Ankara, 2020, s. 275; TÜRKOĞLU, Halide Gökçe, Roma Hukukunda Suç ve Ceza, Ankara, 2017 (Suç ve Ceza), s. 25; SÖĞÜTLÜ, Özlem, Roma Özel Hukuku, Ankara, 2020, s.393, 548; GÜRTEN, Kadir, Roma Hukuku'nda Crimen Kavramı, Ankara, 2016 (Crimen), s. 5; IPEK, Gasp, s. 23.

4 KAYAK, Sevgi, "Roma Hukukunda Görevi Kötüye Kullanma Suçu: D. 48. 11 Metinlerinin Çevirisi ve Tahlili", Prof. Dr. Türkan Rado'nun Anısına Armağan, İstanbul, 2020, s. 745 .

5 Romalıların düşüncesine göre suç işlemek, kişinin kendisinden beklenen davranışı, görevi, sorumluluğu, yükümlülüğü bilerek ya da bilmeyerek yerine getirmemek ya da ihmal etmek anlamına geldiği için delictum kavramı hem özel suç hem de kamu suçu anlamında kullanılmış, yer aldığı metne göre eksiklik, hata, kusur, suç, kabahat anlamlarına gelmiştir. (DEMİiş̦, Bedia, “Eski Roma'nın Edebi Metinlerinde Bir Kavram Olarak Delictum'un Anlamı Üzerine Bir Değerlendirme", Roma Hukukundan Modern Hukuka Sorumluluk Sempozyumu, Cilt: 14, Sayı: 4, 2008, s. 3, 1011.)

6 DI MARZO, Salvatore, Roma Hukuku, İstanbul, 1959, s. 468; RADO, Borçlar, s. 141.

7 SÖĞÜTLÜ ERIŞGİN, Özlem, Roma Hukuku'nda Haksız Fiil Benzerleri (Quasi Delicta), Ankara, 2002, s. 12.

8 DI MARZO, s. 468; RADO, Borçlar, s. 141. 
nırken, kamu suçu sayılan fiillere ilişkin cezalarla benzer davranışların gerçekleştirilmesinin önlenmesi ve toplumun korunması amaçlanmıştır9.

Bu şekilde sınırlı sayıda belirlenen kamu suçları ile çok dar uygulama alanı olan ceza hukuku, klasik dönem hukukçuları için bile yabanc1 kalmış bir kavramdır ${ }^{10}$. Bu süreçte suçun maddi ve manevi unsurdan oluştuğu düşüncesinin izlerini taşıyan uygulamalar bulunmakla beraber, suç teorisinin günümüz hukukundaki şekliyle sistemli hale getirilerek temellendirilmediği görülmektedir ${ }^{11}$.

\section{B. Özel Suçlar}

Özel suçlar, kişilerin menfaatlerini ihlal eden suçlar olarak günümüz Türk hukuku bakımından haksız fiil niteliğinde olan borç kaynağ1nın karşılığını ve tarihsel temelini oluşturmuştur ${ }^{12}$. Roma hukukunda ise, haksız fiil ve suç ayrımı, hukuki ve cezai sorumluluk arasında kesin bir ayrım bulunmadığından, günümüz Türk hukukundaki şekliyle yapilmamıştır ${ }^{13}$.

Suçu işleyen ilk zamanlarda devletin müdahalesi olmaksızın zarar görenin kişisel intikam duygularına ve takibine bağlı olarak cezaland1rılmıştır ${ }^{14}$. Kişisel intikam usulü ile yaptırım, zaman içinde tarafların anlaşmaları sonucu para cezası ödenmesi suretiyle diyet yoluyla yaptı-

9 TÜRKOĞLU ÖZDEMİR, Gökçe, “Roma Hukukunda Rüşveti Engellemeye Yönelik Düzenlemeler", Dokuz Eylül Üniversitesi Hukuk Fakültesi Dergisi, Cilt: 9, Özel Say1, 2007 (Rüşvet), s. 1186.

10 WILINSKI, A., "Roma Ceza Hukuku ve Ceza Usul Hukukuna Bir Kuşbakışı”, Çev.: Belgin Erdoğmuş, Dicle Üniversitesi Hukuk Fakültesi Dergisi, Cilt: 1, Sayı: 1, 1983, s. 329.

11 AYİTER, s. 345; UÇARYILMAZ/EMIROĞLU, s. 848.

12 SÖĞÜTLÜ, s. 552. Bu suçlar bireyin menfaatiyle birlikte kamu menfaatine de zarar vermekteyse, zarar gören kişiler dışında diğer Roma vatandaşlarının da dava açma hakkı bulunmaktadır. (SÖĞÜTLÜ, s. 554.)

13 UMUR, Ziya, Roma Hukuku Ders Notları, İstanbul, 1999 (Ders Notları), s.389; TAHİROĞLU, Bülent, Roma Borçlar Hukuku (Borçlar), İstanbul, 2020, s.297; ERDOĞMUŞ, Belgin, Roma Borçlar Hukuku Dersleri, İstanbul, 2019, s.133; SÖĞÜTLÜ ERIŞGIIN, s. 11.

14 SCHWARZ, Andreas B., Roma Hukuku Dersleri, Cilt: 1, Çev.: Türkan Rado, İstanbul, 1963, s.97; KOSCHAKER, Paul/AYİTER, Kudret, Modern Özel Hukuka Giriş Olarak Roma Özel Hukukunun Ana Hatları, Ankara, 1977, s.22. Kişisel intikam uygulaması aynı zamanda özel suçlar ve kamu suçları ayrımının da özünü oluşturur. Bkz.: Aynı eser s. 260. 
rıma dönüşmüş ${ }^{15}$, devletin müdahalesinin başlamasıyla ödenecek para cezasına, açılan ceza davası sonunda hükmedilmeye başlanmıştır ${ }^{16}$. Bu noktada devletin müdahalesi, ceza uygulamasının düzenlenmesi ve cezanın ölçüsünün belirlenmesi ile sınırlıdır ${ }^{17}$.

Bu sebeple Roma hukukunda borç kaynağ haksız fiil gerçekleştiren, kişi menfaatini ihlal ederek suç işlemiş olur ve açılan ceza davası sonunda para cezasına mahkûm edilerek yaptırıma maruz bırakılır ${ }^{18}$. Para cezası devlete değil zarar görene ödendiği için, ödenen paranın tazminat niteliği olmasa bile ${ }^{19}$, aynı zamanda zarar görenin zararını giderme fonksiyonu da bulunmaktadır ${ }^{20}$. Para cezasına ilişkin borçların mirasçılara geçmemesi, bu borçların konularının kanunla ya da magistra tarafından belirlenen miktarda para olması, sorumluluğun cezai sorumlulukta olduğu gibi hukuki kişiliğe değil gerçek kişiliğe bağlı olarak doğması ve iştirak halinde her suçlunun ayrı ayrı sorumlu tutulması, tazminatın cezai niteliğini ortaya koymaktadır ${ }^{21}$. Haksız fiilden ceza davası doğması prensibi değişmemekle beraber, zamanla haksız fiiller için hem ceza hem tazminat davası açılabilmiştir ${ }^{22}$.

Gaius Institutiones'te belirtildiğ $\mathrm{i}^{23}$ ve Iustinianus Institutiones'te de aynı şekilde tekrar edildiği ${ }^{24}$ üzere ius civile tarafından tanınan özel suç

15 Zamanla kişisel intikam usulünün yerini tarafların sulh anlaşması yaparak bir miktar para ödenmesine karar vermesi usulü almış, bu uygulamanın yükümlülük haline gelmesiyle suçlardan doğan borçlar ortaya çikmıştır. (KOSCHAKER/AYİTER, s. 262-263; KARADENIZ ÇELEBİCAN, s. 278.)

16 RADO, Borçlar, s.141, UMUR, Ders Notları, s.390; ERDOĞMUŞ, s.134; TAHİROĞLU, Borçlar, s. 300.

17 SÖĞÜTLÜ, s. 552-553.

18 TAHİROĞLU, Borçlar, s. 299.

19 KOSCHAKER/AYİTER, s. 260; İPEK, Gasp, s. 25-36.

20 BERKİ, Şakir, "Roma' da Borçların Kaynakları”, Ankara Üniversitesi Hukuk Fakültesi Dergisi, Cilt:11, Sayı:3, 1954, s. 378-413, s. 379; DI MARZO, s. 468-469; RADO, Borçlar, s. 142; KARADENIZ ÇELEBICAN, s. 279.

21 UÇARYILMAZ/EMİRĞLU, s. 842.

22 RADO, Borçlar, s. 142; UMUR, Ders Notları, s. 391; KARADENİZ ÇELEBİCAN, s. 279; TAHIROĞLU, Borçlar, s. 302;TÜRKOĞLU ÖZDEMIR, Rüşvet, s.1186; SÖĞÜTLÜ, s. 395. Iustinianus Dönemi'nde ise hem ceza hem de tazminat davası açılmasına yönelik uygulamanın bulunmadığı, iki işleve de sahip olan karma davaların açıldığ1 görülmektedir. (SÖĞÜTLÜ, s. 554.)

23 Gai. I.3.182.: "Transeamus nunc ad obligationes, quae ex delicto nascuntur, ueluti si quis furtum fecerit, bona rapuerit, damnum dederit, iniuriam commiserit..." 
niteliğindeki haksız fiiller hırsızlık (furtum), gasp (rapina), mala verilen zarar (damnum iniuria datum) ve kişiliğe verilen zarar (iniuria) olmak üzere dört tanedir ${ }^{25}$. Praetor'un tanıdığı hukuki imkânlarla aldatma (dolus), korkutma (metus) ve alacaklılardan mal kaçırma fiilleri de haksız fiil türleri içinde kabul edilmeye başlanmıştı ${ }^{26}$. Ius civile' nin kapsamının bu şekilde genişletilmesine rağmen, Iustinianus Dönemi'nde bile Klasik Hukuk Dönemi'nin haksız fiil tiplerine yönelik yaklaşımı ve bazı haksız fiillerin tek tek düzenlenmesi uygulaması devam etmiştir ${ }^{27}$.

\section{Kamu Suçları}

Roma hukukunun ilk zamanlarında devlet, toplumun zarar gördüğü düşüncesiyle suçları cezalandırmakla ilgilenmişs ${ }^{28}$ ve böylece belirli sayıda suç, dinsel kurallardan yararlanılarak ${ }^{29}$ kamu suçu olarak kabul edilmiştir. İlk zamanlarda kamu suçları sadece vatana ihanet, düşmanla iş birliği yapmak, devlet başkanına suikast ve aile babasının öldürülmesi olarak belirlenmiştir ${ }^{30}$. Tanrılara karşı gelindiği gerekçesiyle, tanrıların

Gai. I.3.182.: “Şimdi haksız fiilden doğan borçlara geçelim, mesela bir kimsenin hırsızlık (furtum) yapması, mal gasp etmesi (rapina), mala zarar vermesi veya kişiliğe tecavüz (iniuria) etmesi gibi..." (RADO, Türkan, Gaius Institutiones, İstanbul, 1953, s. 77.)

24 I. 4.1.pr.: "Cum expositum sit superiore libro de obligationibus ex contractu et quasi ex contractu, sequitur, ut de obligationibus ex maleficio dispiciamus. sed illae quidem, ut suo loco tradidimus, in quattuor genera dividuntur: hae vero unius generis sunt, nam omnes ex re nascuntur, id est ex ipso maleficio, veluti ex furto aut rapina aut damno aut iniuria."

I. 4.1.pr.: "Sözleşmelerden ve sözleşme benzerlerinden doğan borçlardan önceki kitabımızda bahsettikten sonra, haksız fiillerden doğan borçları açıklayalım. Yerinde söylemiş olduğumuz gibi öncekiler dört türe ayrılmaktadırlar: bunlar ise bir tek türdür, hepsi şeyden ( $r e$ ), yani bizzat o haksız fiilden, furtum (hırsızlık ve güveni kötüye kullanma), rapina (gasp), damnum (mala verilen zarar) ve iniuria'dan (kişiliğe tecavüz) meydana gelirler." (UMUR, Ziya, Iustinianus Institutiones, İstanbul, 1968, s. 289.)

25 DI MARZO, s.468; RADO, Borçlar, s.146; UMUR, Ders Notları, s. 391; ERDOĞMUŞ, s. 135; TAHİROĞLU, Borçlar, s. 303; TÜRKOĞLU, Suç ve Ceza, s. 26.

26 RADO, Borçlar, s. 146; ERDOĞMUŞ, s. 135; TÜRKOĞLU, Suç ve Ceza, s. 34.

27 AKINCI, Şahin, Roma Borçlar Hukuku, Konya, 2016, s. 195.

28 KOSCHAKER/AYİTER, s. 22.

29 SÖĞÜTLÜ, s. 549.

30 UMUR, Ders Notları, s. 390; KARADENIZ ÇELEBİCAN, s. 276. On İki Levha Kanunu ile bunlardan başka büyücülük ile zarar verme (Levha 8.1.a, 8.8.), yalan yere tanıklık (Levha 8.23.), kundakçılık (Levha 8.9., 8.10.), gece toplantıları (Levha 8.26.), hâkime rüşvet verme (Levha 9.3.) fiilleri kamu suçu olarak kabul edilmiştir.Dini ge- 
hiddetinden toplumu korumak amaciyla, suç kabul edilen bu fiilleri gerçekleştiren kişiler devlet tarafından cezalandırılmıştır ${ }^{31}$.

Krallık Dönemi'nde kralın iradesi ile belirlenen ${ }^{32}$ ve devlet tarafından takip edilip cezalandırılan kamu suçlarının sayısı, örf ve âdetlerin hukuk üzerindeki etkilerinin azalması ${ }^{33}$, devlet teşkilatının kuvvetlenmesi ve iktidar alanının genişlemesine bağlı olarak zamanla artmıştır ${ }^{34}$. Böylece dini yönü öncelikli olan suç niteliğindeki fiillerin kapsamı, siyasetin etkileriyle değişmiştir ${ }^{35}$. Kişisel intikam usulünün de cezalandırma yöntemi olarak yetersiz kalmasıyla devletin re'sen ceza yargılamasını yürütmesi ve yaptırım uygulaması, kamu düzeninin sağlanması ve hukuk düzeninin devamlılığ için gerekli olmuştur ${ }^{36}$. Bu gelişmenin sonucu olarak kamu suçlarının hem devlet hem de Roma toplumuna mensup

rekçelerle bu suçlar için çoğunlukla ölüm cezası verildiği görülmektedir. Cumhuriyet Dönemi'nin sonlarında kamu suçlarının, aynı şekilde sınırlı sayıda kabul edilmelerine rağmen sayılarının arttığı görülmektedir. Bu dönemde para cezası ile cezalandırılan zar atma, seçim rüşveti gibi yeni suç tipleri ortaya çıkmıştır.İmparatorluk Dönemi'nde de devam eden gelişim sonucunda, suç kabul edilen fiillerin sayısındaki artış, sosyal hayatın ceza hukuku kurallarıyla donatılmasını sağlamıştır. (SCHWARZ, s. 96; WILINSKI, s. 332-333, 335; TÜRKOĞLU ÖZDEMIR, Rüşvet, s. 1182-1183.) Suç işleyenin öldürülmesi şeklinde ağır yaptırıma bağlanan suç tiplerinin, insan onuruyla bağdaşmayan cezaların sayısının az ve sınırlı olması, bireylerin menfaatinin ihlali durumunda benzer yaptırımların istisnalar dışında kabul edilmemiş olması, en basit ifadesiyle insanclllı ilkesi anlamına gelenhumanitas'ın ceza hukuku üzerindeki etkisinin sonuçları olarak kabul edilmiştir. Bu etki, ölüm cezasının daha çok suç tipi için uygulanmaya başlanması sebebiyle İmparatorluk Dönemi'nde azalmıştır. (SCHULZ, Fritz, Principles of Roman Law, Oxford, 1936, s. 202-203, ayrıca ilgili bölümün Türkçe çevirisi için bkz.: SCHULZ, Fritz, “Humanitas", Çev.: Diler Tamer Güven, Argumentum, Cilt: 3, Sayı: 30, 1993, s. 516516; TÜRKOĞLU, Suç ve Ceza, s. 149-150.)

SÖĞÜTLÜ, s. 549; GÜRTEN, Crimen, s. 6. Ayrıca Roma hukukunda kural, kamu otoritesine karşı olan fiillerin cezalandırılması olmuş, sözler ve niyet İmparator $A u$ gustus Dönemi gibi istisnai bazı dönemler dışında cezalandırılmadığından ifade, inanç ve konuşma özgürlüğü gelişmiştir. (TÜRKOĞLU, Suç ve Ceza, s. 37-38.)

32 WILINSKI, s. 330.

33 KARAKOCALI, Hâkim, s. 46.

34 BERKİ, s. 378; IPEK, Gasp, s. 24.

35 SOMER, Pervin, "Roma İmparatorluğunda Seçim Yolsuzlukları ve Ambitus", Marmara Üniversitesi Hukuk Fakültesi Hukuk Araştırmaları Dergisi, Prof. Dr. Bülent Tahiroğlu'na Armağan, Cilt: 23, Say1: 3, 2017, s. 34. 
herhangi biri tarafından takip edilmesi mümkün olmuştur ${ }^{37}$. Bu sayede zarar görenin ceza davası açma imkânı mevcut olmakla beraber, günümüz Türk hukukundakine benzer şekilde bazı suçları devletin takip etmesi uygulaması da yaygınlaşmıştır ${ }^{38}$.

Bu suçlar sosyal düzeni bozduklar ${ }^{39}$, hâkim sınıfın menfaatlerini ${ }^{40}$, kamu yararını ve kamu barışını zedeledikleri gerekçesiyle devlet tarafından takip edilmiş ve suçları işleyenler devlet tarafından cezalandırılmıştır ${ }^{41}$. Dolayısıyla ceza hukukunun gelişimi bakımından ceza yargılamasına ilişkin ilkelerin ve usullerin gelişimi de büyük önem taşımıştır ${ }^{42}$. Ayrıca bu suçlarla kamu menfaati zedelendiğinden, özel suçlara kıyasla kamu suçları daha ağır yaptırımlar uygulanan suçlar olmuşlardır ${ }^{43}$.

\section{TÜRK HUKUKUNDA ŞANTAJ SUÇU}

\section{A. Genel Olarak}

Şantaj suçu, 5237 sayılı Türk Ceza Kanunu'nun ${ }^{44}$ 107. maddesinin birinci fıkrasına göre hakkı olan veya yükümlü olduğu bir şeyi yapacağından veya yapmayacağından bahisle, bir kimseyi kanuna aykırı veya yükümlü olmadığı bir şeyi yapmaya veya yapmamaya ya da haksız ç1kar sağlamaya zorlamak suretiyle, ikinci fıkrasına göre kendisine veya başkasına yarar sağlamak maksadıyla bir kişinin şeref veya saygınlığına zarar verecek nitelikteki hususların açıklanacağı veya isnat edileceği tehdidinde bulunmak suretiyle işlenebilen suç tipi olarak tanımlanmış$\operatorname{tır}^{45}$. İlk fıkra düzenlemesine göre hukuka aykırı sonuç, sahip olunan bir

37 TÜRKOĞLU, Suç ve Ceza, s. 26.

38 RADO, Borçlar, s. 142; TAHIROĞLU, Borçlar, s. 299; SÖĞÜTLÜ, s. 551.

39 TAHİROĞLU, Borçlar, s. 299.

40 WILINSKI, s. 330.

${ }^{41}$ UMUR, Ders Notları, s. 389-390; ERDOĞMUŞ, s. 133-134.

42 KARAKOCALI, Ahmet, Roma Hukukunda Hâkim ve Sorumluluğu, Ankara, 2011 (Hâkim), s. 44-45.

43 GÜRTEN, Crimen, s. 7.

44 Resmî Gazete Tarih: 12/10/2004 Sayı: 25611

45 TCK md. 107: (1) Hakkı olan veya yükümlü olduğu bir şeyi yapacağından veya yapmayacağından bahisle, bir kimseyi kanuna aykırı veya yükümlü olmadığı bir şeyi yapmaya veya yapmamaya ya da haksız çıkar sağlamaya zorlayan kişi, bir yıldan üç yıla kadar hapis ve beş bin güne kadar adlî para cezası ile cezalandırılır.

(2) (Ek: 29/6/2005 - 5377/14 md.) Kendisine veya başkasına yarar sağlamak maksadıyla bir kişinin şeref veya saygınlığına zarar verecek nitelikteki hususların açıkla- 
hakkın veya yükümlülük altında bulunmanın sağladığı imkândan yararlanılarak elde edilmektedir ${ }^{46}$. İkinci fıkra düzenlemesine göre ise, hukuka aykırı sonuca, şeref veya saygınlığa zarar verileceğine ilişkin kötülük bildirimi ile ulaşılmaktadır ve şantaj suçu bu tanımı ile tehdit suçunun özel görünüm şeklini oluşturur ${ }^{47}$.

Türk hukuku bakımından bu şekilde tanımlanan suç tipi ile korunması amaçlanan hukuki değerin ne olduğunun ve suçun unsurları bakımından failin kim olduğunun tespiti de Roma hukuku bakımından yapılacak inceleme için önem taşınmaktadır. Suçun işlenmesi sonucu mağdurun belli bir yönde hareket etmeye zorlanarak iradi hareket özgürlüğünün ihlal edilmesi sebebiyle ${ }^{48}$, kişinin irade serbestisi ve iç hürriyeti ile irade oluşturabilme imkânı, ayrıca ikinci fıkra düzenlemesi bakımından şeref ve saygınlığı, korunan hukuki değer olarak kabul edilmiştir. Suçun maddi bir çıkar elde etmek amacıyla işlenmesi durumunda dolaylı olarak malvarlığı değerlerinin korunması da amaçlanmaktadir ${ }^{49}$.

Suçun birinci fıkrada belirtilen şekli bakımından, kamu görevlileri dışındaki herkes bu suçun faili olabilir ${ }^{50}$. Suçun kamu görevlisi tarafından işlenmesi halinde ise irtikap suçu oluşmaktadır. Suçun ikinci fikrada düzenlenen şekli fail bakımından özellik göstermediği için herkes tarafından işlenebilir suçtur ${ }^{51}$.

Suçun manevi unsuru konusunda birinci fıkra düzenlemesi bak1mından öğretide farklı görüşler bulunmaktadır. Suçun gerçekleşip gerçekleşmemesinde faili harekete geçiren amaca önem verilmediği gerekçesiyle genel kastın yeterli olduğu, aksi yönde ise failin belirli bir amaçla hareket etmesi gerektiği için özel kastın arandığ belirtilmektedir. İkinci

nacağı veya isnat edileceği tehdidinde bulunulması halinde de birinci fıkraya göre cezaya hükmolunur.

46 KOCA, Mahmut/ÜZÜLMEZ, İlhan, Türk Ceza Hukuku Özel Hükümler, Ankara, 2019, s. 416.

47 KOCA/ÜZÜLMEZ, s.416; ÖZBEK, Veli Özer/BACAKSIZ， Pınar/DOĞAN， Koray/TEPE, İlker, Türk Ceza Hukuku Özel Hükümler, Ankara, 2019, s. 415.

48 İrade serbestisinin gerçekten etkilenmiş olup olmadığı suçun oluşması bakımından önem taşımamaktadır. (TEZCAN, Durmuş/ERDEM, Mustafa Ruhan/ÖNOK, Murat, Teorik ve Pratik Ceza Özel Hukuku, Ankara, 2019, s. 502.)

49 KOCA/ÜZÜLMEZ, s. 416-417; ÖZBEK/BACAKSIZ/DOĞAN/TEPE, s. 416.

50 TEZCAN/ERDEM/ÖNOK, s. 502.

51 KOCA/ÜZÜLMEZ, s. 417; ÖZBEK/BACAKSIZ/DOĞAN/TEPE, s. 417. 
fıkra düzenlemesi bakımından ise, failin yarar sağlama amacı sebebiyle özel kast aranmıştır, yarar sağlama amacı bulunmadığında tehdit suçunun varlığı söz konusu olur ${ }^{52}$.

\section{B. Diğer Suç Tiplerinden Farkları}

Şantaj suçunun benzer suç tiplerinden farkları, incelenen konu çerçevesinde cebir, tehdit, görevi kötüye kullanma, irtikap ve rüşvet suçları bakımından önem taşımaktadır.

TCK md. 108 düzenlemesine göre bir şeyi yapması veya yapmaması ya da kendisinin yapmasına müsaade etmesi için bir kişiye karşı fiziki kuvvet kullanılması cebir suçunu oluşturmakta, bu yolla şantaj suçunda olduğu gibi kişinin irade özgürlüğü ihlal edilmektedir. Cebir suçu bakımından fiziki kuvvet kullanılmaktayken, şantaj suçu tehdit yoluyla gerçekleştirilmektedir ${ }^{53}$. Ayrıca şantaj suçunda cebir suçundan farklı olarak mevcut bir hakkın veya yükümlülüğün kötüye kullanılması yoluyla mağdur bir şeye zorlamakta veya haksız çıar elde edilmekte$\operatorname{dir}^{54}$.

Şantaj suçunun, tehdit suçundan farkının tespiti işlenen konu bakımından büyük önem taşımaktadır. TCK md. 106 birinin, kendisinin veya yakınının hayatına, vücut veya cinsel dokunulmazlığına yönelik bir saldırı gerçekleştireceğinden bahisle veya malvarlığı itibarıyla büyük bir zarara uğratacağından veya sair bir kötülük edeceğinden bahisle tehdit edilmesini suç olarak düzenlemiştir. Bu ifadeden anlaşıldığı üzere tehdit suçuyla korunan hukuki değer genel nitelikteyken TCK md. 107/2 ile korunan hukuki değerin ise özel nitelikte olması; tehdit suçunda fiilin yarar sağlama amacı olmaksızın gerçekleştirilmesi söz konusuyken TCK md. 107/2 düzenlemesine göre failin yarar sağlama amacının aranması; tehdit suçunu doğuran fiiller hukuka aykırıyken şantaj suçunu doğuran fiillerin bir hakkın ya da yükümlülügün varlığı sebebiyle hukuka uygun olabilmesi iki suç tipi arasındaki temel farklardır. Tehdit suçunda tehdit

52 Görüşler hakkında bilgi için bkz.: TANER, Fahri Gökçen: “Türk Ceza Hukukunda Şantaj Suçu", Türkiye Barolar Birliği Dergisi, Sayı: 92, 2011, s. 143-144; BİLGE, Burak: "Şantaj Suçu”, İstanbul Medipol Üniversitesi Hukuk Fakültesi Dergisi, Cilt: 6, Say1: 1, 2019, s. 147-148.

53 ÖZBEK/BACAKSIZ/DOĞAN/TEPE, s. 415; TANER, s. 149.

54 BİLGE, s. 153. 
fiilini gerçekleştirmek amaçken şantaj suçunda tehdit fiili araç olarak kullanılmaktadır ${ }^{55}$.

Şantaj suçundan suçun faili bakımından ayrılan görevi kötüye kullanma suçu, irtikap suçu ve rüşvet suçu da konunun incelenmesi bakımından önem taşıyan suç tipleridir. Şantaj suçunun maddi unsurları bu suç tipleri bakımından da gerçekleşmiş olabilir. Bu noktada fark görevi kötüye kullanma, irtikap ve rüşvet alma suçunun faili kamu görevlisi iken, şantaj suçu herkes tarafından işlenebilen suçtur ${ }^{56}$. Suç tiplerinin şantaj suçuyla benzer olduğu nokta ise, tümünün haksız yarar elde etmek amacıyla gerçekleştirilmesidir. Failin, TCK md. 250/1'e göre görevinin sağladığı nüfuzu kötüye kullanmak suretiyle kendisine veya başkasına yarar sağlanmasına veya bu yolda vaatte bulunulmasına bir kimseyi mecbur hissettirmesi icbar suretiyle irtikap suçunu, TCK md. 257/1'e göre kanunda ayrıca suç olarak tanımlanan haller dışında, görevinin gereklerine aykırı hareket etmek suretiyle, kişilerin mağduriyetine veya kamunun zararına neden olması ya da kişilere haksız bir menfaat sağlaması görevi kötüye kullanma suçunu, TCK md. 252/2'ye göre görevinin ifasıyla ilgili bir işi yapması veya yapmaması için, doğrudan veya aracılar vasıtasıyla, kendisine veya göstereceği bir başka kişiye menfaat sağlaması rüşvet alma suçunu doğuracaktır.

\section{ROMA HUKUKUNDA ŞANTAJ FİILININ ÖZEL SUÇ VE KAMU SUÇU NITTELIĞ́̇}

\section{A. Roma Hukukunda Şantaj Fiili}

Türk hukukuna ilişkin düzenlemelere bağlı olarak, Roma hukukunda şantaj fiilinin yerini belirlemek öncelikle kavramın kökenine ve tanımına yönelik incelemeyle mümkün olabilir. Şantaj kavramının tarihi konusunda kaynakların azlığı, kavramın ortaya çıkışına ve tanımına ilişkin belirlemenin, bir şeyi zorla ve baskıyla elde etme fiilinin temel alınarak yapılabilmesi sonucunu doğurmuştur. Buna bağlı olarak şantaj, kişinin kötü bir sonuç doğacağı ve zarara uğrayacağı yönünde inandırıcı şekilde tehdit edilerek, bunun önlenmesi için diğer tarafa para vermek zorunda bırakılması şeklinde tanımlanabilir ${ }^{57}$. Bu konuda yapılması

\footnotetext{
55 TANER, s. 147-148; BİLGE, s. 154-155.

56 TANER, s. 152.

57 HELMHOLZ, R.H., "The Roman Law of Blackmail”, The Journal of Legal Studies, Vol: 30, No:1, 2001, s. 35.
} 
amaçlanan tespit, Türk hukukunun şantaj suçuna ilişkin düzenlemelerinin Roma hukukunda mevcut olup olmadığıdır.

Roma hukukunda leges repetundarum olarak adlandırılan çok sayıda kanun ile kamu görevlilerinin, görevi kötüye kullanarak baskı ve zorlama ile menfaat elde etmeleri yasaklanmış ve bu fiiller kişilerin cezalandırılması yoluyla yaptırıma bağlanmıştır. Bu şekilde baskı ve zorlama ile elde edilen mallar da geri alınmıştır. Bu noktada zedelenen kamu menfaati sebebiyle her vatandaşın yargılama sürecini başlatması ve ayrıca zedelenen özel menfaati sebebiyle maddi kayba uğrayan zarar görenin zararın giderilmesini talep etmesi mümkün olmuştur ${ }^{58}$. Bu sebeple bu kapsamdaki fiillerin hem kamu suçu niteliği hem de özel suç niteliği ortaya çıkabilir ${ }^{59}$.

Zedelenen menfaatin ve yaptırım türlerinin çeşitliliğine rağmen Roma hukukunun bu konudaki tüm düzenlemeleri, şantaj kavramına dahil edilemeyecektir ${ }^{60}$.Bunun için Türk hukukundaki tanıma da uygun olarak fiili gerçekleştirenin zarar verme konusunda, mevcut hakkını kullandığ1 veya yükümlülüğünü yerine getirdiği halde olduğu gibi, gücü olması ve bunun haksız yarar elde etmek amacıyla diğer tarafı zorlayarak tehdit yoluyla kullanılması veya şeref ve saygınlığın zedeleneceğine yönelik tehditte bulunulması gerekmektedir.

58 HELMHOLZ, s. 36.

59 D. 47.13.1.: "Si simulato praesidis iussu concussio intervenit, ablatum eiusmodi terrore restitui praeses provinciae iubet et delictum coercet."

D. 47.13.1.: “Eyalet valisinin sözde talimatına dayanılarak tehdit yoluyla zorlama ve baskı yapma fiili gerçekleştirilmişse, eyalet valisi bu yolla alınan şeyin geri verilmesini sağlayacak ve fiili gerçekleştireni cezalandıracaktır."

D. 47.13.2.: "Concussionis iudicium publicum non est: sed si ideo pecuniam quis accepit, quod crimen minatus sit, potest iudicium publicum esse ex senatus consultis, quibus poena legis Corneliae teneri iubentur, qui in accusationem innocentium coierint quive ob accusandum vel non accusandum, denuntiandum vel non denuntiandum testimonium pecuniam acceperit."

D. 47.13.2.: “Tehdit yoluyla zorlama ve baskı yapma fiiline ilişkin yargılama süreci, Lex Cornelia'nın yargılama sürecini kamusal nitelik taşıyacak şekilde düzenlediği masum kişilerin ihbarı, birine karşı suçlama ileri sürmek tehdidiyle ya da sürmemek amacıyla para alma, yargılama sırasında tanıklık yapmak ya da yapmamak karşılığında para alma suçlarını içeren senato kararına göre, kişi birini kendisine karşı suçlama ileri süreceği yönünde tehdit ederek para almadığı sürece kamusal nitelik taşımaz." 
Şantaj suçunun diğer suç tipleriyle ilişkisi dikkate alınarak benzer tüm fiillerin şantaj kavramı içinde değerlendirilemeyeceği kabul edilmelidir. Bu sebeple tehdit fiili, yarar sağlama amacı olmaksızın hukuka aykırı dayanak ile gerçekleştiriliyorsa şantajın varlığından söz edilemeyecektir.

Roma hukukuna göre, kişilerin hukuka uygun olarak gerçekleştirebilecekleri fiilleri yapmak veya yapmamak yönünde diğer tarafta bask1 oluşturarak menfaat elde etmeleri de kamu görevlisinin menfaat elde etmediği sürece görevinin gereğini yerine getireceği veya getirmeyeceği konusunda diğer tarafı tehdit etmesi de hukuka aykırı kabul edilmiştir. Bununla birlikte şantaj, bu düzenlemelerin varlığı sebebiyle ihtiyaç duyulmadığından, Roma hukukunda ayrıca ve özellikle tek bir suç tipi olarak düzenlenmiş değildir ${ }^{61}$. Şantaj fiili, şeref ve saygınlığı ihlal eden tehdit ile gerçekleştirildiğinde veya kişinin özel menfaatini ve irade özgürlüğünü ihlal ettiğinde özel suç niteliği taşıyacaktır. Buna rağmen fiil, kamusal yetkinin kötüye kullanılması suretiyle kamu menfaatini zedeleyecek şekilde gerçekleştirildiğinde kamu suçu niteliğinde olacaktır.

\section{B. Özel Suç Niteliği}

\section{Kişiliğe Verilen Zarar (Iniuria)}

Haksız yarar sağlamak amacıyla bireyin özel menfaati zedeleniyorsa iniuria olarak adlandırılan fiilin varlığı, bazı durumlarda şantaj fiilinin de varlığını gösterebilmektedir ${ }^{62}$. Bir kişinin başka biri aleyhine yaptığ 1 haksız ve yolsuz fiilleri ifade eden iniuria $^{63}$, bu niteliği ile uygulama alanı başkasının hakkına zarar veren tüm fiilleri içerecek şekilde

61 HELMHOLZ, s. 37.

62 On İki Levha Kanunu'nda vücut bütünlüğünü ihlal eden fiillerle sinırlı olarak korunan kişilik, praetor'un yeni iniuria türlerini kabul etmesiyle başka gerekçelerle de korunmaya başlanmıştır. Hakaret ederek, kişinin şeref ve saygınlığını ihlal ederek, kişinin aile evlatlarına yönelik benzer hareketlerle veya efendinin onuru kırmak amacıyla kölelerine yönelik kötü muamelelerle kişiliğini zedeleyerek zarar verileceği kabul edilmiş, bu fiiller iniuria kapsamına alınmıştır. Hatta kamu hizmetine özgülenmiş şeyden faydalanmaya engel olma fiili de aynı kapsamda kabul edilmiştir. (DI MARZO, s. 479-480.) Böylece söz, yazı veya davranışla kişinin yaşam alanını tehdit eden tüm fiiller iniuria kapsamına alınmıştır. (SÖĞÜTLÜ, s. 590.)

63 D.47.10.1.pr.: "Iniuria ex eo dicta est, quod non iure fiat: omne enim, quod non iure fit, iniuria fieri dicitur..."

D.47.10.1.pr.: "Hukuka aykırı olarak yapılan her şeye iniuria denir, zira hukuka aykırı olarak yapılan şey iniuria yani haksız olarak yapılmış demektir." (SÖĞÜTLÜ, s. 546.) Iniuria kelimesi haksızlık anlamına gelmektedir. (UMUR, Ders Notları, s. 395.) 
geniş olan ${ }^{64}$, aynı zamanda diğer ceza davalarının açılamadığı hallerde tamamlayıcı niteliği olan özel suçtur ${ }^{65}$. Roma hukukunda şantaj fiilinin ayrı bir suç tipi olarak düzenlenmemesinin yarattığı boşluk, iniuria'ya ilişkin hükümlerle doldurulmuştur. Iniuria'nın geniş kapsamı ve uygulaması sebebiyle şantaj fiilinden zarar görenler için hukuki koruma sağlanmış, fiilin ayrıca bir suç tipi olarak düzenlenmesine ihtiyaç duyulmamıştır ${ }^{66}$.

On İki Levha Kanunu'nda yer alacak şekilde ${ }^{67}$ Roma hukukunun ilk zamanlarından itibaren hukuka aykırı olarak kişiliğe yapılan saldırıları ifade etmek için kabul edilen iniuria ${ }^{68}$, ilk zamanlar sadece bedensel bütünlüğe verilen hafif zararlar bakımından tanımlanmıştır69. Daha sonra bir uzvun koparılması ve kemiğin kırılması şeklinde gerçekleştirilen ağır yaralama fiilleri de bu kapsamda kabul edilmeye başlanmıştır. Bu niteliği ile kavramın maddi şiddet ile gerçekleştirilen, bedene yönelik hukuka aykırı saldırıları ifade ettiği kabul edilir ${ }^{70}$. Bunun sonucunda ağır yaralamalar için kişisel intikam duygusunu tatmin etmeye yönelik kısas uygulaması kabul edilmiş, hafif ve iz bırakmayan yaralamalar için kısas yerine para cezası uygulanmıştır ${ }^{71}$.

Şantaj fiili ile bağlantı kurulabilmesi için önem taşıyan kişiliğe verilen zarar kavramı ise, iniuria'nın kapsamına dahil olan bedensel bütünlüğe yönelik saldırılardan değil, iniuria verbalis olarak adlandırılan ve praetor faaliyetleri sonucunda gelişen kavramlarla ortaya çıkan ${ }^{72}$, kişinin şeref ve saygınlığı gibi kişilik haklarına ve manevi kişiliğine yönelik söz-

\footnotetext{
64 DI MARZO, s. 97.

65 HONIG, Richard, Roma Hukuku, İstanbul, 1938, s. 288.

66 HELMHOLZ, s. 37-38.

67 Levha 8.2., 8.3., 8.4.

68 GÜNEŞ PESCHKE, Seldağ, Roma Hukukundan Günümüze Kişilik Haklarının Korunması (Iniuria), Ankara, 2014, s. 44.

69 AKINCI, s. 207; TÜRKOĞLU, Suç ve Ceza, s. 32.

70 RADO, Borçlar, s.153; UMUR, Ders Notları, s. 395; TAHİROĞLU, Bülent, Roma Hukukunda Iniuria, İstanbul, 1969 (Iniuria), s. 17-19.

71 TAHİROĞLU, Iniuria, s. 23, 37.

72 SÖĞÜTLÜ, s. 586.
} 
lü saldırılardan doğmaktadır ${ }^{73}$. Bu niteliği ile kavram, geniş anlamda kişiliğe yönelik hukuka aykırı fiilleri ifade etmek için kullanılmıştır ${ }^{74}$.

Ayrıca kişilerin haklarını kullanmasını engelleyici bütün fiiller iniuria kapsamındadır ${ }^{75}$. Dolayısıyla kişiyi haksız yarar sağlamak amacıyla bir şeyi yapmaya veya yapmamaya zorlayacak şekilde kişilik hakları ihlaliyle ya da kişinin şeref ve saygınlığına yönelik tehditle şantaj fiilinin gerçekleştirilmesi, iniuria kapsamında kabul edilebilir ${ }^{76}$. Kişiyi aşağılayacak, küçük düşürecek, onurunu zedeleyecek, sırlarını açıklayarak şeref ve saygınlığına zarar verecek hareketlerin ${ }^{77}$ gerçekleştirileceğine yönelik tehditle haksız yarar elde eden kişi şantaj fiilini gerçekleştirmiş olacak ve iniuria sebebiyle sorumlu olacaktır.

Geniş tanımına bağlı olarak iniuria'nın varlığı, her durumda şantaj fiilinin gerçekleştirilmiş olduğunu göstermez. Bunun için şantaj suçunu düzenleyen TCK md. 107/2'nin ifadesine uygun olarak şeref ve saygınl1ğa zarar verecek hususun açıklanacağı veya böyle bir husus olmasa bile isnat edileceği tehdidi oluşmalıdır. Örnek olarak kişinin borçlarını ödemeyen biri olduğu bilgisinin yayılarak şeref ve saygınlığına zarar verileceği tehdidinde, kişi gerçekten böyle biri olsa da olmasa da toplumdaki saygınlığını yitirmesi, kurmuş olduğu ya da kuracağı borç ilişkilerinin zedelenmesi, dolayısıyla her durumda zarar görmesi mümkündür ${ }^{78}$. Bu durumda kişinin zarar göreceği yönünde tehdit edilmiş olması sebebiyle şantaj fiilinin gerçekleştirildiği kabul edilebilir. Burada gerçekleştirilen fiilin kesin olarak zarar doğuracak nitelikte olması koşulu aranmakta, örneğin toplum tarafından şerefli ve saygın olarak görülmeyen birinin şeref ve saygınlığına zarar vermek mümkün olmayacağından şantaj fiiline maruz kalamayacağı kabul edilmektedir ${ }^{79}$. Buna karşın kişinin borçlarını ödemeyen biri olduğu bilgisi doğruysa ve bu bilgi hukuka uygun

73 TAHİROĞLU, Iniuria, s. 114-118; GÜNEŞ PESCHKE, s. 49.

74 TAHİROĞLU, Iniuria, s. 11.

75 TAHİROĞLU, Borçlar, s. 320-321.

76 Iniuria kavramının kapsamının genişletilmesinin sebeplerinden biri, yerleşmiş örf ve âdet uygulamalarında bozulmaların gerçekleşmesidir. Tehdit, görevi kötüye kullanma, buna bağlı olarak şantaj gibi uygulamaların yaygınlaşması bu bozulmalardan biridir. (TAHİROĞLU, Iniuria, s. 118-121.) Dolayısıyla uygulamanın genişletilmesinin sebeplerinden birinin, bu fiilleri önleme amacı olduğu düşünülebilir.

77 GÜNEŞ PESCHKE, s. 85, 88.

78 HELMHOLZ, s. 38.

79 HELMHOLZ, s. 40. 
şekilde veya kamu menfaatini korumak amacıyla, bir hakkın kullanılması ya da yükümlülüğün yerine getirilmesi suretiyle açıklanıyorsa ${ }^{80}$ hakkın ya da yükümlülüğün sağladığı imkândan faydalanarak zarar verme amacı olmadığ1 için ${ }^{81}$ şantaj fiilinin gerçekleştiği söylenemez. Bu noktada uygulamanın TCK md. 107/1 düzenlemesi ile de bağlantısı ortaya çıkmaktadır. Dolayısıyla bu hak ve yetkilerin hukuka aykırı şekilde zarar verme amacıyla kullanılması şantaj fiilinin mevcut olduğunu gösterebilir.

Bu konuya ilişkin bir diğer örnek, insanların kendisinden iğrenmesine ve uzaklaşmasına sebep olacak hastalığının açılanacağı ve bu suretle kişinin şeref ve saygınlığına zarar verileceği yönünde tehdit edilmesi durumunda diğer unsurları da mevcutsa şantaj fiilinin gerçekleştiği kabul edilebilir. Buna rağmen söz konusu hastalık bulaşıcı nitelikteyse ve kamu sağlığını tehlikeye atıyorsa, kamu menfaatinin bulunması sebebiyle bu bilginin açılanması hukuka uygundur ${ }^{82}$.

Iniuria'nın varlığının şantaj fiilinin gerçekleşmiş olduğunu göstermesi için aranması gereken bir diğer unsur, zarar verme amacıyla bağlantılı olarak fiili gerçekleştirenin haksız yarar sağlama amacının varlığıdır. Mevcut bir hakkın veya yükümlülüğün sağladığı imkândan faydalanılarak kişinin irade özgürlüğünün ya da şeref ve saygınlığına zarar verileceği yönünde tehdit edilerek kişilik haklarının ihlalini gerçekleştiren kişi, bu fiili ile haksız yarar elde etmeyi amaçlamalıdır. Aksi durumda hukuka aykırı davranışın iniuria olduğu söylenebilirken şantaj fiili niteliğinde olduğu söylenemez.

Iniuria kapsamına girecek şekilde gerçekleşen saldırılarda zarar görene, On İki Levha Kanunu ile iniuria davaları açma hakkı tanınmış, bu davalar daha sonra praetor'un geliştirdiği ve zararın doğmasından itibaren bir yıl içinde açılması gereken actio iniuriarum şeklinde tek bir dava olarak kabul edilmiştir ${ }^{83}$. Böylece sabit para cezaları yerine, her davada zarara göre belirlenen takdiri para cezalarına hükmedilmiş ve suçun ağırlığı sebebiyle karar tek hâkim önünde değil, hâkimler heyeti

\footnotetext{
80 HELMHOLZ, s. 39-40.

81 GÜNEŞ PESCHKE, s. 103-104.

82 HELMHOLZ, s. 40-41.

83 UMUR, Ziya, Roma Hukuku Lügatı, İstanbul, 1983 (Lügat), s. 8; TAHİROĞLU, Iniuria, s. 160.
} 
önünde verilmiştir ${ }^{84}$. Bununla birlikte, iniuria'nın kapsamı genişlediğinden, praetor'un tanıdığ 1 dava ile bedensel bütünlüğe verilen zararlar d1şındaki zararlar için de talepte bulunmak mümkün olmuştur ${ }^{85}$.

Ceza davası niteliği sebebiyle davayı zarar gören kişi açabilmektedir ve zedelenen değer kişilik hakları olduğundan istisnalar dışında mirasçıların dava açma hakkı bulunmamaktadır ${ }^{86}$. Ayrıca bu saldırılar sebebiyle mahkûm olan kişinin infamis (şerefsiz) olacağ 1 da kabul edilmiş$\operatorname{tir}^{87}$.

İlk İmparatorluk Dönemi'nde kişilik hakları ve şeref kavramının gelişmesiyle uygulama alanı daha da genişletilen iniuria, bu dönemde kamu suçu niteliği de kazanmıştır ${ }^{88}$. Iustinianus Dönemi'nde hukuka aykırı hareketlerin, hâkim tarafından haksız karar verilmesinin, kişinin onuruna yönelik hakaret içeren fiillerin iniuria kapsamında olduğu belirtilmektedir ${ }^{89}$.

\section{Korkutma (Metus)}

Kişinin, bir hakkın veya yükümlülüğün gereği olan şeyin yapılacağı ya da yapılmayacağı veya şeref ve saygınlı̆̆ına zarar verecek hususların açılanacağı şeklinde tehdit edilmesi yoluyla praetor'un tanıdığı özel suçlardan olan metus, yani korkutma fiilinin ${ }^{90}$ gerçekleştirildiği durumlarda unsurları bulunduğu sürece şantaj fiilinin de gerçekleştirildiğini kabul etmek mümkün olabilir. Kişinin hukuka aykırı şekilde zorlanması sonucu zihninde kötülüğe veya tehlikeye maruz kalacağı kanaatinin oluşması ile iradesinin ortaya çıkması, metus'un varlığını göster-

84 RADO, Borçlar, s. 154; ERDOĞMUŞ, s. 144; TAHİROĞLU, Iniuria, s. 163; GÜNEŞ PESCHKE, s. 100-101.

85 TAHIROĞLU, s. 161-162; GÜNEŞ PESCHKE, s. 105.

86 RADO, Borçlar, s. 154; TAHİROĞLU, Iniuria, s. 176.

87 TÜRKOĞLU ÖZDEMIR, Gökçe, Roma Hukukunda Infamia (Şerefsizlik), Ankara, 2008 (Infamia), s. 174.

88 TAHİROĞLU, Iniuria, s. 231, 234-235; SÖĞÜTLÜ, s. 591.

89 GÜNEŞ PESCHKE, s. 42-43.

90 Metus'un, iradenin sakatlanması bakımından ius civile tarafından dikkate alınmamasının sonucu olarakkorkutma sebebiyle yapılan hukuki işlemler geçerli kabul edilmiş, praetor hukukunun tanıdığı imkânlarla uygulama değişmiştir. (UMUR, Lügat, s. 136.) 
mektedir ${ }^{91}$. Roma hukukunda metus'un, zarar görene ceza davası niteliğindeki korkutma davası açma imkânı tanınması sebebiyle özel suç niteliği de bulunmaktadır. Bu sebeple kişiyi, yapmayacağı fiili ya da hukuki işlemi korku yaratarak haksız ve yolsuz şekilde yapmaya itmek anlamına gelen metus'a, tamamlayıcı niteliği sebebiyle açılabilecek başka bir dava hakkının bulunmadığı durumlarda başvurulabilecektir ${ }^{92}$.

Şantaj suçu ile metus arasındaki bağlantının anlaşılabilmesi için öncelikle metus kurumunun hukuki düzenlemelerde yer almasina duyulan ihtiyacın sebeplerini belirlemek önemlidir. Cumhuriyet Dönemi'nin sonlarında metus'a ilişkin düzenlemelerin ortaya çıkması, dönemin toplumsal ve siyasal karışıklarla geçmesinin sonuçlarından biridirr ${ }^{93}$. Korku yaratarak haksız ve yolsuz sonuçlar elde etmek ve zor kullanmak, bu dönemde sıklıkla başvurulan yöntemlerden olmuştur ${ }^{94}$. Toplumun ve hukuk sisteminin gelişmesine bağlı olarak, dönemin sonlarında zorla ve korkunun etkisiyle gerçekleştirilen hukuki işlemleri yaptırıma bağlama fikri yerleşmeye başlamıştır ${ }^{95}$. Kamu görevlilerinin de başvurduğu hukuka aykırı bu yöntemler kamu menfaatinin zedelenmesi durumunda kamu suçu oluştururken, diğer kişilerin benzer davranışları sonucunda zarara uğrayanların zararlarının giderilmesi ihtiyacı doğmuştur. Bu noktada metus'un, politik menfaatlerle kamu görevlileri tarafından başvurulan yolsuzluk yöntemlerinden biri olmasi ${ }^{96}$, kurumun düzenlenmesine duyulan ihtiyacın göstergelerindendir.

Bu şekilde malvarlıklarını vermeleri, verecekleri taahhüdünde bulunmaları, malvarlıkları üzerindeki haklardan ve miras haklarından feragat etmeleri gibi konularda baskıya maruz kalarak, özel olarak korunma ihtiyacı ortaya çıkan kişilerin çeşitli hukuki yollarla korunması sağlanmıştır ve bu hukuki yollardan biri praetor'lar tarafından geliştiri-

91 IPEK, Nurcan, “Roma Hukukunda Korkutma (Metus)”, Marmara Üniversitesi Hukuk Fakültesi Hukuk Araştırmaları Dergisi, Prof. Dr. Bülent Tahiroğlu'na Armağan, Cilt: 23, Sayı: 3, 2017 (Korkutma), s. 102.

92 HONIG, s. 289.

93 KARAKOCALI, Ahmet, Roma Hukukunda ve Türk Hukukunda Korkutma (Metus), Ankara, 2016 (Korkutma), s. 37-38.

94 IPEK, Korkutma, s. 110.

95 GLOVER, Graham, "Metus in the Roman Law of Obligations", Fundamina: A Journal of Legal History, Sayı:10, 2004, s. 35.

96 ZIMMERMANN, Reinhard, The Law of Obligations: Roman Foundations of the Civilian Tradition, Cape Town, 1992, s. 655-656. 
len metus olmuştur ${ }^{97}$. Metus'a ilişkin talep haklarının ve dava usulünün ortaya çıkışı ile eyaletlerde işlenen kamu suçları olan crimen repetunda$r u m^{\prime} \mathbf{u}^{98}$ yargılayan ceza mahkemelerinin gelişimi de ilişkilendirilmekte$\operatorname{dir}^{99}$.

Kişide veya kişinin yakınlarında ciddi anlamda korku, endişe ve kaygı oluşturularak ${ }^{100}$ bu kişilerin canlarına, özgürlüklerine, şereflerine, namuslarına yönelik manevi şiddet gösterilmesi ${ }^{101}$ suretiyle yapmak istemedikleri bir hukuki işlemi yapmaya zorlanmalar1 ${ }^{102}$ durumunda, korkutma olarak tanımlanan özel suç niteliği ortaya çıkacaktır. Bu şekilde kişi yapmış olduğu işlemi kendi isteği ile yapmıştır ve dolayısıyla işlemi gerçekleştirmeye yönelik rızası vardır ${ }^{103}$; fakat işlemi yapmayı istemeye manevi baskı ile korkutularak mecbur bırakılmıştır ${ }^{104}$. Bu sebeple rızanın varlığı kabul edilmesine rağmen, rıza gösterenin zarar görmemek amacıyla işlemi yapması sebebiyle özgür iradesinin kırıldığı belirtilmektedir ${ }^{105}$. Bu şekilde korkutma, şantaj fiilinin gerçekleştirilmesi suretiyle de ortaya çıkabilir ${ }^{106}$.

Metus'un hangi durumlarda şantaj fiilinin gerçekleştirilmesi suretiyle ortaya çıktığının tespiti için iki kurumun unsurlarının kıyaslanması gerekmektedir. Şantaj suçunu düzenleyen TCK md. 107/1 düzenlemesine göre korunan hukuki değerin kişinin irade özgürlüğü olması, metus bakımından da önem taşır. Metus sonucunda da kişi kendi iradesi ile belirli bir şey yapmaya yönlendirilmektedir ${ }^{107}$. Burada da irade, kişinin korkutulması yoluyla sakatlanmaktadır ve kişi kendisinden istenen şeyi

97 KARAKOCALI, Korkutma, s. 39.

98 Konuya ilişkin bilgi için bkz.: IV/C. Kamu Suçu Niteliği bölümü

KARAKOCALI, Korkutma, s.42; IPEK, Korkutma, s.115; ÖNCÜL, Ayşe, Metus Kavramı ve Kurumlarının İncelenmesi, İstanbul, 2018, s. 14.

Korku, endişe ve kaygı oluşturan durumlara örnek olarak, Digesta metinlerinden anlaşıldığı üzere statü ve özgürlüğün kaybı, ölüm, hapis cezası alma, cinsel saldırıya uğrama verilebilir. (KARAKOCALI, Korkutma, s. 72-73.)

UMUR, Lügat, s. 136.

RADO, Borçlar, s. 156; UMUR, Ders Notları, s. 208-209; TAHİROĞLU, Borçlar, s. 328; SÖĞÜTLÜ, s. 594-595.

106 UMUR, Ders Notları, s. 208.

107 ÖNCÜL, s. 94. 
yapmadığı sürece zarara uğrayacağı korkusu yaşamaktadır. Bu korku, TCK md. 107/1'de düzenlendiği üzere bir hakkın kullanılacağı ya da yükümlügün yerine getirileceği gerekçesiyle yaratılabileceği gibi, metus ile korunan şeref, namus gibi hukuki değerlere yönelik olarak TCK md. 107/2' de düzenlendiği üzere şeref ve saygınlığın zarar göreceği gerekçesiyle de yaratılabilir.

Metus ve şantaj suçu arasındaki bağlantının belirlenebilmesi için bazı Digesta metinleri aydınlatıcı olmaktadır:

D.4.2.3.1.: "Sed vim accipimus atrocem et eam, quae adversus bonos mores fiat, non eam quam magistratus recte intulit, scilicet iure licito et iure honoris quem sustinet. Ceterum si per iniuriam quid fecit populi Romani magistratus vel provinciae praeses, Pomponius scribit hoc edictum locum habere: si forte, inquit, mortis aut verberum terrore pecuniam alicui extorserit."

D.4.2.3.1.: "Ancak burada anlaşılması gereken güç kullanımı aşırı şiddettir ve bir magistra'nın hukuk çerçevesinde makamının kendisine verdiği gücü uygulaması değil, ahlak kurallarına aykırı olarak kullanılmış bir güç olmalıdır. Bununla birlikte Romalı bir magistra ya da bir eyaletin valisi ölüm korkusu yaratarak rüşvet almak gibi hukuka aykırı bir fiil gerçekleştirdiği zaman, Pomponius'un da söylediği üzere edictum bu kişi için de geçerli olacaktır."108

$\mathrm{Bu}$ metne göre hakkın kullanılacağı veya yükümlülüğün yerine getirileceği yönündeki açıklamalar, hukuka aykırı olmadığı sürece metus'u doğurmaz. Örneğin kişinin borçluyu kendisine olan borcunu ödememesi sebebiyle borcu ödemeye zorlaması, dava açma hakkını kullanacağını bildirmesi ${ }^{109}$ hukuka aykırı manevi baskı ve korkutma değildir. Metus için gereken, hakkın hukuka aykırı şekilde kullanılması ve diğer tarafta zarara uğrama korkusu yaratılarak haksız yarar elde etmenin amaçlanmasıdır. Bu unsurlar aynı zamanda şantaj suçunun unsurları olduğundan, korkutmanın bu şekilde şantaj fiilinin gerçekleştirilmesi ile sağlanması da mümkündür. Benzer nitelikte bir örnek şu şekildedir:

D. 4.2.8.1.: "Si is accipiat pecuniam, qui instrumenta status mei interversurus est nisi dem, non dubitatur quin maximo metu compellat, 
utique si iam in servitutem petor et illis instrumentis perditis liber pronuntiari non possum."

D. 4.2.8.1.: "Bir kişinin eğer kendisine ödeme yapmazsam sivil statümü belirleyen belgelerden mahrum birakmakla tehdit ederek benden para alması halinde aşırı korku nedeniyle baskı altında olduğuma şüphe yoktur, ne de olsa beni köle statüsüne getirmekle tehdit etmiştir ve bu belgeler olmazsa özgür olduğum beyan edilemez."110

D. 4.2.3.1. metnindeki diğer bir kavram şiddet kavramıdır. Kişiyi olumlu veya olumsuz davranışı yapmadığı takdirde zarar göreceği yönünde tehdit etmek suretiyle kişinin zihninde korku yaratılarak gerçekleştirilen manevi şiddet, Orta Çağ hukukunda geliştirilen vis compulsiva kavramı ile ifade edilmektedir. Kişinin iradesi bu şekilde manevi şiddet gösterilerek sakatlandığından vis compulsiva, metus'un önemli unsurlarındandır ${ }^{111}$. Maddi şiddet ise, fiziksel olarak uygulanan güç ile kişinin iradesi olmaksızın bir şey yapmaya yönlendirilmesine sebep olacağı için metus'un unsurlarından değildir. Metus bu niteliğiyle, fiziki kuvvet içermeyen şantaj suçunun unsurları ile de uyumludur.

D. 4.2.7.1.: "Proinde si quis in furto vel adulterio deprehensus vel in alio flagitio vel dedit aliquid vel se obligavit, Pomponius libro vicensimo octavo recte scribit posse eum ad hoc edictum pertinere: timuit enim vel mortem vel vincula. Quamquam non omnem adulterum liceat occidere, vel furem, nisi se telo defendat: sed potuerunt vel non iure occidi, et ideo iustus fuerit metus. Sed et si, ne prodatur ab eo qui deprehenderit, alienaverit, succurri ei per hoc edictum videtur, quoniam si proditus esset, potuerit ea pati quae diximus."

D. 4.2.7.1.: “Aynı şekilde hırsızlık ya da zina ediminde ya da herhangi bir diğer utanç verici davranışta bulunurken yakalanan bir kişi herhangi bir şeyi hediye eder ya da bir yükümlülük altına girerse, Pomponius haklı olarak, yirmi sekizinci kitabında bu şahsın ölüm ya da hapisten korktuğundan bu hükme başvu-

110 KARAKOCALI, s. 76.

111 GLOVER, s. 48; KARAKOCALI, Korkutma, s. 33; İPEK, Korkutma, s. 106-107; ÖNCÜL, s. 9-11. Hem kamu suçları hem de özel suçlar bakımından şiddet ve kaba kuvveti ifade eden vis kavramı, baskı ve şiddete dayalı olarak yapılan tüm fiilleri içerecek şekilde geniş kapsamlıdır. (GÜNDAY, Onur, Cumhuriyet Dönemi Roma Toplumunda Kamu Suçları, Yargılamalar ve Ceza Uygulamaları, Ankara, 2019, s. 64-65.) 
rabileceğini yazmaktadır. Kendisini bir silahla savunmadıkça zina yapan birisini ya da bir hırsızı öldürmek her zaman kanuna uygun olmasa da bu şahıs kanuna uygun olmayan şekilde yine de öldürülebilir ve bu nedenle korku haklı çıkarılmış olur. Gene bu hükmün altındaki tesellinin, kendisini yakalayan kişi tarafından ele verilmesin diye -çünkü ele verilirse belirttiğimiz cezalara maruz kalabilir- mülkü devreden birine verilmesi gerektiği ileri sürülmektedir."112

Bu metinden anlaşıldığ leyen kişinin, bu konuda sessiz kalma karşılığında başkasına haksız yarar sağlaması, ceza alacağı ve ayrıca şeref ve saygınlığının zarar göreceği korkusu ile manevi baskı altında olmasına bağlanmıştır. Metus ile şantaj suçunun unsurlarının benzediği noktalar buradan da anlaşılmaktadır.

Metus'un gerçekleştirilmesi durumunda zarar görenin malvarlığındaki eksilme giderilmezse ${ }^{113}$ ceza davası niteliği olan Klasik Sonrası Hukuk Dönemi'ndeki adiyla actio quod metus causa yani korkutma davası ile ${ }^{114}$,dava bir yıl içinde açıldıysa zararın dört katına kadar, bir yıldan sonra açıldıysa zarar kadar para cezasına hükmedilmiştir ${ }^{115}$. Bu dava şerefsizlik sonucunu doğurmamış ${ }^{116}$, korkutan elde ettiği menfaati üçüncü kişiye devretmişse dava bu kişiye karşı da açlabilmiştir ${ }^{117}$. Davanın bu şekilde üçüncü kişilere karşı açılabilmesi ve elde edilen menfaat iade edildiğinde artık dava açılamaması Iustinianus Dönemi'nde gerçekleştiğinden, bu dönemde davanın ceza davasından ziyade tazminat davası niteliğinde olduğu kabul edilmektedir ${ }^{118}$. Ayrıca bu yolla iadeyi gerçek-

112 ÖNCÜL, S. 61.

113 KARAKOCALI, Korkutma, s. 80-81. Ayrıca açılabilecek ceza davası bulunması durumunda ceza davası ile korkutma davası yarışmakta, iade korkutma davasının sonucuna göre gerçekleşmiş olsa da suçu işleyen ceza davası ile de yaptırıma maruz birakılmaktadır. (İPEK, Korkutma, s. 176-177.)

114 İPEK, Korkutma, s. 131.

115 Bunun dişında korkutma sebebiyle borç ilişkisi kurulması durumunda, eski hale iade ve korkutma def'i imkânlarıyla zarar görenin farklı hukuki yollarla korunması da sağlanmıştır. (RADO, Borçlar, s. 156-157; TAHİROĞLU, Borçlar, s. 329.)

116 İPEK, Korkutma, s. 139-140.

117 KASER, Max, Roman Private Law, Çev.: Rolf Dannenbring, Pretoria, 1984, s.59; UMUR, Ders Notları, s. 208.

118 RADO, Borçlar, s. 156-157; GLOVER, s. 41; IIPEK, Korkutma, s. 135; ÖNCÜL, s. 103104. 
leştiren kamu görevlileri, crimen repetundarum'un sonuçlarından korunmuştur ${ }^{119}$. Eğer metus, şantaj fiilinin gerçekleştirilmesiyle ortaya çıkmışsa, bu yollarla şantaj fiili de yaptırıma bağlanmış olacaktır.

\section{Kamu Suçu Niteliği}

Cumhuriyet Dönemi'nin sonlarından itibaren Roma Devleti'nin büyüklügü ve kamu hukuku alanında yaşanan gelişmeler, Romalıların insanlığa ve insan haklarına yönelik yaklaşımlarıyla birlikte değerlendirildiğinde, yönetenler ile yönetilenler bakımından hukuka uygun olan ve aynı zamanda keyfi uygulamalardan, şiddetten, haksız menfaat elde etmekten uzak davranışlar göstermek önem kazanmıştır. Ahlaki yapıdaki bozulmanın sonucu olarak yolsuzluğun olağan hale gelmesi ${ }^{120}$, kamu menfaatini ve anayasal düzeni bozduğu ölçüde mücadele edilmesi gereken sorun olarak kabul edilmiştir. Özellikle eyaletlerde yaşayanların, denetimden uzak olan kamu görevlilerinin yozlaşmaya bağlı olarak artan ve bir yaşam biçimi haline gelen görevi kötüye kullanma fiilleri sebebiyle zarara uğradığ1 görülmektedir ${ }^{121}$. Bu yönde gerçekleştirilen fiillerin artması sebebiyle konuya ilişkin hukuki düzenlemelere yer verme ihtiyacı doğmuş, leges repetundarum adıyla temelde rüşveti engellemeyi amaçlayan kanunlar çıkarılmıştır ${ }^{122}$.

Bu kanunların çokluğu ve kapsamları sorunun büyüklüğünü göstermektedir. Buna rağmen kanunlar, merkezden uzak eyaletlere gönderilen kamu görevlileri bakımından tek başlarına sorunun tamamen ortadan kalkmasını sağlamamışlardır ${ }^{123}$. Düzenlemelerden yararlanan suç mağdurlarının içinde, suçu işleyenler gibi nüfuz sahibi kamu görevlilerinin bulunması, düzenlemelerin rakiplere karşı politik anlamda rekabet

119 KASER, s. 59. Crimen repetundarum kavramı ile ilgili bilgi için bkz.: IV/C. Kamu Suçu Niteliği bölümü

120 SOMER, s. 38-42.

121 ZIMMERMANN, s. 651-652; GLOVER, s. 36.

SHERWIN-WHITE, A.N., "The Lex Repetundarum and the Political Ideas of Gaius Gracchus", The Journal of Roman Studies, Vol: 72, 1982, s. 20; RICHARDSON, J.S., "The Purpose of the Lex Calpurnia de Repetundis", The Journal of Roman Studies, Vol: 77, 1987, s. 1-2; TÜRKOĞLU, Halide Gökçe, "Roma Hukukunda Humanitas ile Maiestas Populi Romani Arasındaki Bağlantı", Türkiye Barolar Birliği Dergisi, Sayı: 96, 2011, (Humanitas), s. 248. Roma hukukuna göre, Romalı kamu görevlisinin Roma' da yaşayan herhangi bir kişiden ya da Roma Devleti dışındaki herhangi bir tüzel kişiden hukuka aykırı olarak elde ettiği maddi menfaat rüşvet olarak kabul edilmektedir. (SOMER, s. 43.) 
etmek amacıyla kullanıldığını göstermektedir ${ }^{124}$. Bu politik amacın kanunların yapılış amacı olarak kabul edilmesi doğru bir değerlendirme olmamasına rağmen ${ }^{125}$, kanunların toplumsal yozlaşmayı önleme ve ortadan kaldırma fonksiyonuna engel olduğu düşünülebilir.

Repetundae kavramı, magistra'ların yetkilerini kötüye kullanarak zorla edindikleri ve kendilerinden geri alınabilen para ve malları ifade etmektedir ${ }^{126}$. Crimen repetundarum olarak adlandırılan suçlar ise, hukuka aykırı şekilde para ve mal alınması amacıyla gerçekleştirilen ${ }^{127}$ haraç kesme, hile yapma, rüşvet alma, irtikap ve şantaj fiillerini kapsayan suç tipi olarak kabul edilmiş ve kamu suçları içinde değerlendirilerek ${ }^{128} \mathrm{dev}$ lete karşı işlenen suçlar arasında yer almıştır. M.Ö. 59 tarihinden itibaren kamu idaresine karşı işlenen bütün suçlar bu kapsamda kabul edilmiştir $^{129}$. Bu suçların işlenmesi tehditle mal ve para alınması suretiyle gerçekleştirilmekte, yapılan düzenlemelerle tehdit altında kalan kişi verdiği mal ve parayı geri isteyebilme imkânına sahip olmaktadır ${ }^{130}$. Bununla birlikte kamusal görevin, ihmal sebebiyle hiç veya gereği gibi yerine getirilmemesi de bu kapsamda değerlendirilir. Bu genel niteliğiyle görevi kötüye kullanmak suretiyle elde edilen her türlü haksız yarar repetundae olarak kabul edilecektir ve görevi kötüye kullanma suçu kamusal görevin sağladığı nüfuz kullanılarak rüşvet alma, irtikap ve benzeri fiillerin gerçekleştirilmesiyle işlenebilir ${ }^{131}$.

Önemli makamlarda bulunanların kararları dürüstçe ve vicdanlı şekilde vermelerinin ${ }^{132}$ ve görevlerini hukuka uygun şekilde yerine getirmelerinin sağlanması amacıyla bu fiiller, sadece magistra'lar, diğer

124 SHERWIN-WHITE, s. 71.

125 TÜRKOĞLU ÖZDEMIR, Rüşvet, s. 1200.

126 SMITH, William, Dictionary of Greek and Roman Antiquities, London, 1853, s. 986; BERGER, Adolf, Encyclopedic Dictionary of Roman Law, Philadelphia, 1953, s. 675; SHERWIN-WHITE, s. 20; UMUR, Lügat, s. 182; ZIMMERMANN, s. 652 dn. 8.

TÜRKOĞLU ÖZDEMIR, Gökçe, "Roma Hukukunda Hâkimin Sorumluluğu”, Marmara Üniversitesi Hukuk Fakültesi Hukuk Araştırmaları Dergisi, Cilt: 14, Sayı: 4, 2008 (Hâkimin Sorumluluğu), s. 286; ÖZER SARITAŞ, Duygu, Roma Ceza Hukuku'nda Daimî Ceza Mahkemeleri (Quaestiones Perpetuae), Bursa, 2020, s. 12. TÜRKOĞLU ÖZDEMIR, Rüşvet, s. 1183.

AYİTER, s. 351.

130 GÜNDAY, s. 105.

131 KAYAK, s. 750, 763-764.

TÜRKOĞLU ÖZDEMİ, Hâkimin Sorumluluğu, s. 302. 
kamu görevlileri ve avukatlar tarafından gerçekleştirildiğinde suç olarak kabul edilmektedir ${ }^{133}$. Böylece resmi makamlarda bulunanların konumlarını kişisel menfaat elde etme amacıyla kullanmaları sorumluluklarına sebep olacaktır ${ }^{134}$. Ayn fiilin kamu görevlisi tarafından, kamu menfaatini korumak amacıyla gerçekleştirmek zorunda olduğu bir fiil olması durumunda görev kötüye kullanılmış olmamakta ve zarar doğmuş olsa bile fiil suç teşkil etmemektedir ${ }^{135}$.

Büyük çoğunlukla maddi menfaat elde etmek amacıyla işlenen ${ }^{136}$ bu suç tipine Cumhuriyet Dönemi'nin başlarında nadiren rastlanmış, dönemin ilerleyen zamanlarında yozlaşmaya bağlı olarak çok sayıda düzenlemeye konu olacak derecede yaygın suç tipine dönüşmüştür ${ }^{137}$. Cumhuriyet Dönemi'ndeki yaygın niteliği, politik sebeplerle İlk İmparatorluk Dönemi'nde kaybolmuş ve düzenlemeler büyük değişikliğe uğramıştır ${ }^{138}$.

Şantaj fiilinin, kamusal yetkinin kötüye kullanılması yoluyla kamusal menfaati ihlal edecek şekilde gerçekleştirildiği durumlarda, kamu suçu niteliği ortaya çıkacak ve bahsedilen yapısı dikkate alındığında crimen repetundarum kapsamında kabul edilebilecektir. Şantajın crimen repetundarum kapsaminda kabul edilebilmesine dayanak olarak, Digesta metinlerinde yer verilen bazı düzenlemeler gösterilebilir. Digesta'nın 47. kitabının 13. faslının düzenlemelerine göre ${ }^{139}$ magistra'nın ya da sahte şekilde magistra'nın yerine geçen kişinin tehdit yoluyla insanlardan para veya hediye alması suç olarak kabul edilmiş, kamu idaresiyle ilgili işlerde şantaj anlamına gelen ${ }^{140}$ ve crimen concussionis olarak adlandırılan bu

133 HARRIES, Jill, Law and Crime in the Roman World, Cambridge, 2007, s. 61; TÜRKOĞLU, Suç ve Ceza, s. 46.

134 HELMHOLZ, s. 37.

135 HELMHOLZ, s. 40.

136 GÜRTEN, Kadir, “Roma' da Devlete Karşı İşlenen Bazı Suçlar ve Cezaları”, Ankara Barosu Dergisi, Cilt: 75, Sayı: 3, 2017 (Suçlar), s. 65.

TÜRKOĞLU, Suç ve Ceza, s. 47. Ayrıca On İki Levha Kanunu'nda hâkimlerin görevlerini yapmak için rüşvet almaları durumunda ölüm cezası ile cezalandırılacaklarının düzenlenmesi, görev sebebiyle menfaat elde etmeye yönelik davranışların Cumhuriyet Dönemi'nin başlarında da hukuki düzenlemelerde yer aldığını göstermektedir.

WILINSKI, s. 334.

139 Metinler ve çevirileri için bkz: yuk. dn. 59.

140 AYİTER, s. 351. 
suç zamanla crimen repetundarum'un kapsamina dahil edilmiştir ${ }^{141}$. Bu durumda zorlama ve baskı ile haksız yarar sağlayan fail magistra olduğunda kamu görevlisi tarafından şantaj fiili gerçekleştirilmiş ve irtikap suçu olarak düzenlenen suç işlenmiş olacaktır. Fail magistra yerine geçen kişiyse mevcut bir hakkın kullanılması ya da yükümlülügün yerine getirilmesi söz konusu olmadığı sürece şantaj fiilinin varlığı kabul edilemez.

Bir diğer düzenleme D. 48.11.7.pr.'da yer almaktadır:

D. 48.11.7.pr.: "Lex Iulia de repetundis praecipit, ne quis ob iudicem arbitrumve dandum mutandum iubendumve ut iudicet: neve ob non dandum non mutandum non iubendum ut iudicet: neve ob hominem in vincula publica coiciendum vinciendum vincirive iubendum exve vinculis dimittendum: neve quis ob hominem condemnandum absolvendumve: neve ob litem aestimandam iudiciumve capitis pecuniaeve faciendum vel non faciendum aliquid acceperit."

D. 48.11.7.pr.: "Lex Iulia de Repetundis, bir yargilama veya tahkim yapmak için; yargılamayı değiştirmek ya da birine vermek için; yargılama ya da hakemliği yapmamak, onu değiştirmek, onu engellemek için; bir adamı kamusal bir yere hapsetmek, zincirlemek veya zincirlememek için; onu hukuki/fiili zincirlerinden kurtarmak için; mahkûm etmek veya bağışlamak için; bir mahkûmiyet miktarı saptamak için; parasal veya hürriyeti bağlayıcı bir cezaya çarptırmak veya çarptırmamak için herhangi bir şey kabulünü yasaklamıştır."142

$\mathrm{Bu}$ metinde sayllan kamusal görevlerin yerine getirileceği veya getirilmeyeceği ileri sürülerek haksız yarar elde edildiğinde fiilin suç teşkil edeceği kabul edilmiştir. TCK md. 107/1 düzenlemesine uygun olarak hak veya yükümlülüğün sağladığı imkândan faydalanma unsuru ve haksız yarar elde etme amacı burada da bulunmaktadır. Bununla birlikte metinde bahsedilen fiilin şantaj suçu niteliğinde olabilmesi için kişinin sayılan hak ve yükümlülüklerin yerine getirileceği veya getirilmeyeceği konusunda tehdit altında hissederek irade özgürlüğünün ihlal edilmesi ve haksız yarara sebep olacak şeyi yapmaya veya yapmamaya zorlanması gerekmektedir.

Bu değerlendirmeler sonucunda kamu görevlisi şantaj fiilini gerçekleştirdiğinde Türk hukukundaki ifadesiyle irtikap suçu gerçekleşmiş

\footnotetext{
141 BERGER, s. 403; TÜRKOĞLU, Suç ve Ceza, s. 47 dn. 122.

142 KAYAK, s. 741.
} 
olacak ve crimen repetundarum'un öngördüğ̈̈ cezaların uygulanmasıyla kamu görevlisi bu yolla aldıklarını iade etmek zorunda kalacaktır. Zaman içinde fiili gerçekleştireni cezalandırma düşüncesi öne çıktığından suçu işleyen, zararın iki katını ödeme ya da kamu görevlisinin görev süresinin dolmasından itibaren bir yıl içinde talep edilirse zararın dört katını ödeme şeklinde para cezasına mahkûm edilecektir ${ }^{143}$. Böylece bu suça ilişkin cezaların kişisel intikam alınması amacıyla değil, mağdurun zararını giderme amacıyla belirlendiği görülmektedir ${ }^{144}$.

Cezai ve hukuki yaptırım niteliğinin iç içe geçtiği uygulamalardan biri kabul edilebilecek şekilde, bazı durumlarda suçun işlenmesinden fail dışındaki kişiler de sorumlu olabilmektedir. Suçun işlenmesi ile maddi menfaat elde edilmesi hali sebepsiz zenginleşme niteliğindeyse, suçlunun ölümünden itibaren bir yıl boyunca mirasçıları da para cezaları bakımından suçtan sorumlu tutulmuştur ${ }^{145}$.

İmparatorluk Dönemi'nde sinıfsal statünün ve sahip olunan makamın kaybı ve bazen sürgüne gönderilme cezalarının uygulandığı görülmektedir ${ }^{146}$. Ayrıca bu dönemde ceza yargılamasındaki değişimlerin de etkisiyle açılan davaların para iadesine yönelik dava olmasından ziyade ceza davası olması niteliği ön plana çıkmıştır ${ }^{147}$. Sulla sonrası dönemde, artan yozlaşmanın önüne geçilmesi amaciyla zaman zaman ölüm cezasının uygulandığı da görülmektedir ${ }^{148}$.

143 TÜRKOĞLU ÖZDEMİ, Hâkimin Sorumluluğu, s. 287; GÜNDAY, s. 106.

144 HARRIES, s. 71.

145 GÜRTEN, Suçlar, s. 67.

D. 48.11.2.: "Datur ex hac lege et in heredes actio intra annum dumtaxat a morte eius qui arguebatur."

D. 48.11.2.: "Kanuna göre bu dava, suçlananın ölümünden itibaren bir yıl içinde onun mirasçılarına karşı da ikame edilir." (Çeviri için bkz.: KAYAK, s. 739.)

TÜRKOĞLU, Suç ve Ceza, s. 47.

147 KAYAK, s. 762-763.

148 GÜRTEN, Suçlar, s. 66.

D. 48.11.7.3.: "Hodie ex lege repetundarum extra ordinem puniuntur et plerumque vel exilio puniuntur vel etiam durius, prout admiserint. Quid enim, si ob hominem necandum pecuniam acceperint? Vel, licet non acceperint, calore tamen inducti interfecerint vel innocentem vel quem punire non debuerant? Capite plecti debent vel certe in insulam deportari, ut plerique puniti sunt."

D. 48.11.7.3.: “Lex Iulia de Repetundis kapsamında suçlu olan bir kimseye takdir yetkisi kullanılarak ceza verilir ve bu ceza genellikle sürgün olur. Ancak kabul edilen rüşvet, bir kimsenin ölümünün karşılığı içinse nasıl bir ceza verilmelidir? Ya da 
Şantaj fiilinin gerçekleştirilmesi durumunda mağdurun, suçu işleyen hâkim veya başka bir kamu görevlisi olsa bile, kabul edilen ceza davaları dişında iniuria veya metus için tanınan hukuki imkânlardan faydalanması da mümkündür ${ }^{149}$. Bunun için kamu görevlisinin görevini yaparken yetkisinin sınırlarını aşmış olması veya kamu görevlisi dışında herhangi bir birey gibi davranmış olması gerekmektedir ${ }^{150}$.

Ceza hukuku alanındaki gelişmelere bağlı olarak zaman içinde, belirli suç tipleri için yargılama yetkisi özel kanunlarla halk meclisleri yerine mahkemelere verilmiştir ${ }^{151}$. Bu şekilde yetkilendirilen ve bir magistra'nın başkanlık ettiği daimî ceza mahkemeleri olan quaestionesperpetuae $^{152}$ mahkemelerinin ${ }^{153}$ kökeni, crimen repetundarum' $u$ yani eyalet vali-

rüşvet kabul edilmese dahi kızgınlıkla masum bir kimsenin ölümüne veya cezalandırılmasına sebebiyet verilmişse verilecek ceza nasıl olmalıdır? Bu gibi durumlar için en uygun cezalar, ölüm ya da sürgün cezasıdır." (Çeviri için bkz.: KARAKOCALI, s. 157.)

Zarar görenin bu yolla korkutma davası açarak verdiğinin dört katını talep edebilmesi, davanın görevlinin görev süresinin dolmasından itibaren bir yıl içinde açılması ile mümkündür. (TÜRKOĞLU ÖZDEMIR, Hâkimin Sorumluluğu, s. 284-285.)

150 D. 47.10.32.: “Nec magistratibus licet aliquid iniuriose facere. Si quid igitur per iniuriam fecerit magistratus vel quasi privatus vel fiducia magistratus, iniuriarum potest conveniri..."

D. 47.10.32.: "Magistra'ların iniuria yaptıkları kabul edilemez. Bununla beraber, bir magistra hususi bir şahıs olarak veya magistra makamının kendisine verdiği yetkiyi kullanarak iniuria yaparsa, ona karşı iniuria davası açılabilir..." (Bilgi ve çeviri için bkz.: TAHİROĞLU, Iniuria, s. 203 dn. 96.)

151 Cumhuriyet Dönemi'nde magistra'lar dışında, belli durumlarda yargılama yetkisi olan halk meclisleri, magistra' nın verdiği mahkûmiyet kararının tekrar görüşüldüğü bir ceza mahkemesi işlevi görmüşler, magistra'ların ceza yargılamasına ilişkin yetkilerinin sınırlanmasıyla birlikte vatandaşlar tarafından işlenen kamu suçlarının yargilandığ1 mahkemeler haline gelmişlerdir. (GÜRTEN, Crimen, s. 22-23.) Halk meclislerinin yerini daimî ceza mahkemelerinin alması, halk meclislerinde yargılamaların uzun sürmesi ve bunun da ötesinde toplumsal ve siyasal değişimlere bağlı olarak yargılama sisteminin güncellenmesine ihtiyaç duyulması sebebiyle aşamalar halinde gerçekleşmiştir. (ÖZER SARITAŞ, s. 9-11.)

$152 \mathrm{Bu}$ mahkemeler önceleri İtalya ve eyaletlerde kamu görevlileri tarafından Roma vatandaşı olmayanlardan haksız olarak alınanların iadesi iddialarını dinlemiş, zamanla mahkemelerin sayılarını, işlevlerini arttıran ve yeni suç ve ceza türleri öngören düzenlemeler yapılmıştır. Yargılama ile görevli magistra'ların menfaat elde etme, taraflı olma gibi davranışlarını engelleyen bu yargılama usulü, ceza hukuku alanında adil yargılama uygulamasının da önünü açmıştır. (KARAKOCALI, Hâkim, s. 50.) 
lerinin işlediği irtikap suçunu da içerdiğini kabul ettiğimiz kamu suçlarını işleyen ve görevlerini kötüye kullanan kamu görevlilerinin yarg1lanması için ${ }^{154}$ M.Ö. 149 tarihli Lex Calpurniade Repetundis adlı kanunla kurulan quaestiode repetundis ${ }^{155}$ adlı mahkemeye dayanmaktadır ${ }^{156}$. Romalı eyalet yöneticilerinin eyaletlerdeki Roma vatandaşı olmayan yabancilardan şantaj fiilini gerçekleştirerek işledikleri irtikap suçu sonucunda elde ettikleri maddi menfaatlerin iadesini sağlayan ${ }^{157}$ kanun, bu yönüyle parasal nitelikte cezalar öngörmüştür ${ }^{158}$. Daha sonra çıkarılan kanunlardan ise, söz konusu kanunların para cezası dişında cezalar öngörmesi noktasında ayrilmaktadır ${ }^{159}$.

Bu kanundan sonra aynı konuya ilişkin olan, aynı zamanda usule ilişkin değişiklikler içeren ${ }^{160}$ M.Ö. 126 tarihli Lex Iunia de Pecuniis Repetundis ${ }^{161}$, M.Ö. 123 tarihli Lex Sempronia de Repetundis, M.Ö. 123 veya 122

154 Söz konusu suçlara ilişkin hukuki düzenlemelerin yapılması, temelde Roma eyaletlerinde ve taşrada yaşayan uyrukları, yetkiye sahip olan, gücü elinde tutan, belirli sosyal sınıflara ve ailelere mensup kişilerin sömürüsünden koruma amacına dayanmaktadir. (GÜNDAY, s. 245.)

155 Praetor'un başkanlık ettiği ve her biri başka bir suç tipinin yargılanması için kurulmuş ceza mahkemeleri olan quaestio'lar, önceleri sorgu hâkimliği niteliğindeyken zamanla daimî ceza mahkemeleri haline gelmiş, İmparatorluk Dönemi boyunca yavaş yavaş önemlerini yitirmişlerdir. (UMUR, Lügat, s. 175.)

BERGER, s.663; WILINSKI, s. 331; AYİTER, s. 350; UMUR, Lügat, s. 175; BAUMAN, Richard A., Crime and Punishment in Ancient Rome, London, 2004, s.22-23; HARRIES, s. 16-17, 61; TÜRKOĞLU, Suç ve Ceza, s. 199 dn. 147; ÖZER SARITAŞ, s. 44.

UMUR, Lügat, s. 115. Ayrıca kanun, Cicero tarafından insan haklarının korunması bakımından öncü kabul edilmiştir. (BAUMAN, s. 23; TÜRKOĞLU, Humanitas, s. 258.) Kanunun eyaletlere ilişkin düzenlemesinin temelinde, kamusal gücün ve makamların kötüye kullanılmasının devlet yapısı üzerindeki olumsuz etkileri ve söz konusu suçların işlenmesi ile ekonomik çıkarların zedelenmesi sebepleriyle Roma vatandaşlarını koruma amacı olduğu görüşü bulunmaktadır. Aynı görüşe göre bu kanun ile takip eden kanunlar arasındaki temel fark, sonraki kanunlarda aynı koruma amacının vatandaş olmayanlar için de gözetilmiş olmasıdır. (RICHARDSON, s. 8, 11.) Sonraki kanunların ayrım gözetilmeksizin Roma sınırları içinde yaşayan herkesi koruduğu yönündeki benzer görüş için bkz.: SHERWIN-WHITE, s.20; HARRIES, s. 62.

SMITH, s. 986; TÜRKOĞLU ÖZDEMIR, Rüşvet, s. 1190; ÖZER SARITAŞ, s. 50. GÜNDAY, s. 244.

SMITH, s. 986. Ayrıca kanun hakkında yeterli bilgi bulunmadığı ve yapılış tarihinin Lex Calpurnia de Repetundis'ten daha eski olabileceği yönündeki bilgi için bkz.: KAYAK, s. 754. 
tarihli Lex Acilia de Repetundis ${ }^{162}$, M.Ö. 100 tarihli Lex Servilia Glaucia de Repetundis ${ }^{163}$, M.Ö. 81 tarihli Lex Cornelia de Repetundis ve M.Ö. 59 tarihli Lex Iulia de Repetundis kanunları çıkarılmıştır164. Tüm bu kanunlar suçu işleyenin infamis (şerefsiz) kabul edileceği yönünde düzenleme içermektedir ${ }^{165}$, ayrıca bu cezanın kanunların çıkarılma gerekçelerine benzer sebeplerle yetersiz kabul edilmesi sonucunda cezalar zamanla ağırlaştırilmıştır ${ }^{166}$.

Lex Iunia de Pecuniis Repetundis ile daha önceki para cezası düzenlemesinden farklı olarak, suçu işleyene sürgün cezası verileceği düzenlenmiştir ${ }^{167}$.

Lex Sempronia de Repetundis suçun işlenmesini önlemeye yönelik düzenlemelerin yanı sıra hâkimlerin seçilme usullerine ilişkin düzenlemeler içermektedir ${ }^{168}$. Suç işleyen magistra'nın, kamusal işlerin aksama-

162 Ceza yargılamasının en temel kanunlarından biri olan bu kanun, quaestiones perpetuae mahkemelerinin yapısına ve yargılama şekline ilişkin detaylı düzenlemeler içermektedir. (KARAKOCALI, Hâkim, s. 50-51.) Kanunun yapılış tarihinin belirsiz olduğu ve muhtemelen M.Ö. 101 tarihinde yapılmış olabileceği hakkında bilgi için bkz.: SMITH, s. 986.

163 Kanunun yapılış tarihine ilişkin farklı bilgiler bulunmaktadır. M.Ö. 111 tarihli olduğuna ilişkin bilgi için bkz.: BERGER, s. 560; M.Ö. 111 veya 108 tarihli olduğuna ilişkin bilgi için bkz.: UMUR, Lügat, s. 124; M.Ö. 100 tarihli olduğuna ilişkin bilgi için bkz.: SMITH, s. 986; ÖZER SARITAŞ, s. 55; M.Ö. 106-100 yılları arasında çıkarılmış olduğuna ilişkin bilgi için bkz.: GÜNDAY, s. 246.

164 TÜRKOĞLU, Suç ve Ceza, s.199. Bu kanunlar dışında söz konusu suçlara ilişkin yargılamanın usulünü düzenleyen senatus kararları da bulunmaktadır. Bunlar içinde M.Ö. 4 tarihli Senatus Consultum Calvisianum ve M.S. 47 tarihli Senatus Consultum Claudianum sayılabilir. (BERGER, s.697; TÜRKOĞLU ÖZDEMİR, Rüşvet, s.11951196.)

165 Magistra'ların ve diğer kamu görevlilerinin görevlerine yakışmayacak davranışlarla yetkilerini kötüye kullanarak menfaat elde etmeleri şeklinde işledikleri suçlar, bu kişilerin şerefsiz kabul edilmeleri yoluyla yaptırıma bağlanmıştır. (TÜRKOĞLU ÖZDEMIR, Infamia, s. 105-106.) TÜRKOĞLU, Humanitas, s. 259. TÜRKOĞLU ÖZDEMİ, Rüşvet, s. 1192; ÖZER SARITAŞ, s. 51.

168 UMUR, Lügat, s. 124. Ayrıca kanunun, suç işleyen kamu görevlilerin, kamu görevlisi olmayan babalarının ve oğullarının işlerin yürütülmesine katıldıkları düşüncesiyle sorumlu tutulabileceği yönünde yorumlandığı görülmektedir. (SHERWINWHITE, s. 19.) 
sının önlenmesi amacıyla görev süresi tamamlanmadan yargılanamayacağ1 kabul edilmiştir ${ }^{169}$.

Lex Acilia de Repetundis sebebiyle mahkûm olanlar zararın iki katını ödeme ${ }^{170}$, infamia'nın sonucu olarak hâkim sıfatıyla davalara bakamama, patronus sifatıyla mahkemelerde bulunamama ${ }^{171}$ yaptırımlarına maruz kalmaktadırlar. Kanunun içeriği hakkında çok detaylı bilgi olmamakla beraber, zayıf konumdaki mağdurun, suçu işleyen nüfuz sahibi kamu görevlisi karşısındaki durumunu dengeleyecek hukuki düzenlemeler içermesi bakımından önemi büyüktür ${ }^{172}$.

Lex Servilia Glaucia de Repetundis'in zararın iki katının ceza olarak ödenmesi düzenlemesi, ilerleyen zamanlarda zararın dört katının ceza olarak ödenmesi uygulamasına dönüşmüştür ${ }^{173}$. Suçun işlenmesi ile kişisel menfaatlerin zedelenmesinin ötesinde, devletin ulusal güvenliğinin ihlal edilmesi durumunda ölüm cezasının uygulanacağı öngörülmüştür ${ }^{174}$. Yine aynı kanun hâkim listelerinin oluşturulması usulüne ilişkin düzenleme içermekte, suç işleyen magistra' yı mahkûm ettiren yabanciya Roma vatandaşlığ 1 verileceğini kabul etmektedir ${ }^{175}$. Diğerlerinden daha sert hükümler içeren bu kanunla ilk kez politik hakların kaybı suça ilişkin ceza olarak belirlenmiştir ${ }^{176}$. Bu kanunla da suç işleyen magistra'nın görev süresi tamamlanmadan yargılanamayacağ 1 kabul edilmiştir ${ }^{177}$.

169 SHERWIN-WHITE, s. 24, 29.

170 BAUMAN, s. 23. Bu miktarı ödeyerek aciz duruma düşecek olanlar için sürgün cezası uygulandığı görülmektedir. (TÜRKOĞLU ÖZDEMİR, Rüşvet, s.1202; GÜNDAY, s. 246.)

171 Bu kanunla önemli makamlarda bulunmuş kamu görevlileri olan davalıların, eyaletlerde yaşayan güçsüz halkın karşısında yargılama sırasında avantajlı olmalarının doğurduğu sakıncalar giderilmeye çalışılmış, davacılara mahkeme sürecinde yardımcı olmaları için patronus adlı kişiler atanmıştır. (TÜRKOĞLU ÖZDEMİR, Rüşvet, s. 1193; ÖZER SARITAŞ, s. 54.) Ayrıca yabancı birinin bir magistra' yı bu kanuna dayanarak mahkûm ettirmesi, Roma vatandaşlığını kazanmasını sağlamaktadır. (UMUR, Lügat, s. 113-114.)

172 TÜRKOĞLU ÖZDEMIR, Rüşvet, s. 1192-1193.

173 SMITH, s. 986; ÖZER SARITAŞ, s. 55-56.

174 BAUMAN, s. 23.

175 UMUR, Lügat, s. 124. Roma vatandaşlığ verilmesine ilişkin düzenleme, Lex Sempronia de Repetundis adlı kanunda da bulunmaktadır. (SHERWIN-WHITE, s. 29 v.d.) Ayrica bkz.: yuk. dn. 173 .

176 BERGER, s. 560.

177 SMITH, s. 986. 
Lex Cornelia de Repetundis ise hem suçun kapsaminı daha önceki kanunlarda belirtilen fiillerin benzerlerini kapsayacak şekilde genişletmiş hem de verilecek cezaları, ateş ve su kullanımının yasaklanması şeklinde yasaklar da ekleyerek ağırlaştırmıştır ${ }^{178}$.

Lex Iuliade Repetundis ile suçun kapsamı konuya ilişkin herhangi bir kabahati veya ihlali kapsayacak şekilde genişletilmiş ${ }^{179}$, sadece maddi menfaat elde etmeyi değil, makamı suistimal etmeyi de cezalandırma amaçlanmıştır. Bir yargı kararı verilmesi veya verilmemesi konusunda yetki sahibi olanlarm, bu sebeple maddi menfaat elde edemeyecekleri açıkça belirtilmiştir ${ }^{180}$. Ayrıca suçu işleyenlerin mahiyetlerinin de kanuna uymakla yükümlü olacağına yönelik genişleme de bu düzenleme ile olmuştur $^{181}$. Böylece magistra'ların, yetki sahibi tüm kişilerin ve ayrıca işleri birlikte yürüttükleri kişilerin de suça karışmaları ve menfaat elde etmeleri durumunda sorumlu olacağ 1 kabul edilmiştir ${ }^{182}$. Mahkûm olanlar sürgün yerine senatus'tan ihraç edilme ve bir daha senatus'a üye olamama, mahkemede tanıklık edememe ${ }^{183}$, hâkim olamama yaptırımlarına maruz kalmaktadırlar ${ }^{184}$. Ayrıca bu yolla elde edilen şeylerin, zamanaşımı ile iktisap edilemeyeceği kabul edilmiştir ${ }^{185}$.

Lex Iulia de Repetundis'e ilişkin düzenlemeler, Digesta'nın 48. kitabının 11. faslında yer almaktadır. Hangi fiillerin bu kapsamda suç teşkil ettiği ve verilecek cezalar metinlerde açıkça düzenlenmiştir. Bu düzenlemeler kapsamında kamu görevlilerinin ve yargılama yapan kurullarda görev alanların, kamusal görevleri ve diğer resmi görevleri sebebiyle maddi menfaat elde etmeye yönelik fiilleri bu kanuna göre suç teşkil edecektir ${ }^{186}$. Bu fiillerin neler olduğu, daha önce incelenen ve şantaj fiili ile bağlantısı belirlenen D. 48.11.7.pr. metninde düzenlenmiştir.

\footnotetext{
178 SMITH, s. 986; TÜRKOĞLU ÖZDEMIR, Rüşvet, s. 1194; ÖZER SARITAŞ, s. 56-57.

179 BERGER, s. 555.

180 D. 48.11 .3$.

181 HARRIES, s. 65; TÜRKOĞLU ÖZDEMIR, Hâkimin Sorumluluğu, s. 284; GÜRTEN, Suçlar, s. 65.

182 D. 48.11.1.pr. Ayrıca kanun Iustinianus Dönemi'nde de yürürlükte kalmıştır. (UMUR, Lügat, s. 120-121.)

183 SMITH, s. 987.

184 TÜRKOĞLU ÖZDEMIR, Infamia, s. 79, 81.

185 TÜRKOĞLU ÖZDEMIR, Rüşvet, s. 1194.

186 BERGER, s. 675; HELMHOLZ, s. 36; KAYAK, s. 755-756.
} 
Son İmparatorluk Dönemi'nde halkın ve amirlerinin suç işlediğini bilen kamu görevlilerinin, bahsedilen suçları işleyen kamu görevlilerini şikâyet etmeleri gerektiği imparatorlar tarafından bildirilmiştir ${ }^{187}$.

\section{SONUÇ}

Roma hukukunda suç kavramı, On İki Levha Kanunu'nun içeriğinde yer alacak kadar eski zamanlardan itibaren iki gruba ayrılarak incelenmiş, suç ve haksız fiil kavramları arasında ayrım gözetilmemiştir. Suçların kapsamının çok dar olduğu ilk dönemlerde bütün haksız fiiller aynı zamanda suç sayılmıştır ve suçlar, bireyin menfaatinin veya kamu menfaatinin zarar görmesine bağlı olarak özel suçlar ve kamu suçları şeklinde ikiye ayrılmıştır. Delictum privatum veya delictum olarak adlandırılan ve Türk hukukunda haksız fiil olarak nitelendirilen özel suçlar, zarar gören tarafından takip edilen ve özel kişilerin menfaatlerini ihlal eden suçlardır. Delictum publicum veya crimen olarak adlandırılan kamu suçları ise, gerçekleştirilen fiilin Roma halkına yönelik olduğu kabul edildiğinden kamu menfaatini ihlal eden, sınırlı sayıda belirlenen ve devlet tarafından takip edilip cezalandırılan suçlardır.

$\mathrm{Bu}$ kavramlar doğrultusunda incelenen şantaj suçu, Türk hukuku bakımından hakkı olan veya yükümlü olduğu bir şeyi yapacağından veya yapmayacağından bahisle, bir kimseyi kanuna aykırı veya yükümlü olmadığı bir şeyi yapmaya veya yapmamaya ya da haksız çıkar sağlamaya zorlamak suretiyle ya da kendisine veya başkasına yarar sağlamak maksadıyla bir kişinin şeref veya saygınlığına zarar verecek nitelikteki hususların açıklanacağ suretiyle işlenebilen suç tipi olarak tanımlanmıştır. Roma hukukuna göre ise, şantaj suçu ayrıca ve özellikle tek bir suç tipi olarak düzenlenmiş değildir. Şantaj fiili şeref ve saygınlığı ihlal eden tehdit ile gerçekleştirildiğinde, mağdurun özel menfaatini ve irade özgürlüğünü ihlal ettiğinde özel suç niteliği taşıyacaktır. Buna rağmen fiil, kamu menfaatini zedeleyecek şekilde kamusal yetkinin kötüye kullanılması suretiyle gerçekleştirildiğinde kamu suçu niteliğinde olacaktır.

Şantaj fiili ile bireyin özel menfaatini zedeleyecek şekilde haksız yarar sağlandığında iniuria olarak adlandırılan fiilin varlığı söz konusu olabilmektedir. Bir kişinin başka biri aleyhine yaptığı haksız ve yolsuz fiilleri ifade eden iniuria, bu niteliği ile uygulama alanı başkasının hakkına zarar veren tüm fiilleri içerecek şekilde geniş olan, aynı zamanda 
diğer ceza davalarının açılamadığı hallerde tamamlayıcı niteliği olan özel suçtur.

Şantaj fiilinin, kişinin şeref ve saygınlığına zarar verecek hususların açıklanacağı şeklinde tehdit edilmesi yoluyla gerçekleştirildiği durumda ise, praetor'un tanıdığı özel suçlardan olan metus'un varlığ 1 kabul edilebilir. Bu sebeple kişiyi, yapmayacağı fiili ya da hukuki işlemi korku yaratarak haksız ve yolsuz şekilde yapmaya itmek anlamına gelen metus'a, tamamlayıcı niteliği sebebiyle başvurulabilecektir.

Crimen repetundarum olarak adlandırılan suçlar ise, hukuka aykırı şekilde para ve mal alınması amacıyla gerçekleştirilen haraç kesme, hile yapma, rüşvet alma, irtikap ve şantaj fiillerini kapsayan suç tipi olarak kabul edilmiş ve kamu suçları içinde değerlendirilerek devlete karşı işlenen suçlar arasında yer almıştır. Bu suçların işlenmesi tehditle mal ve para alınması suretiyle gerçekleştirilmekte, yapılan düzenlemelerle tehdit altında kalan kişi verdiği mal ve parayı geri isteyebilme imkânına sahip olmaktadır. Bu şekilde kamusal yetkinin kötüye kullanılması ile kamusal menfaati zedeleyen şantaj fiilleri, leges repetundarum olarak adlandırılan kanunlar doğrultusunda yaptırıma bağlanacaktır. 


\section{KAYNAKLAR}

AKINCI, Şahin: Roma Borçlar Hukuku, Konya, 2016.

AYİTER, Kudret: “Roma Ceza Hukukunda Quaestiones Perpetuae ve Cognitio Extra Ordinem", Ahmet Esat Arsebük'e Armağan, Ankara, 1958, s. 339-368.

BAUMAN, Richard A.: Crime and Punishment in Ancient Rome, London, 2004.

BERGER, Adolf: Encyclopedic Dictionary of Roman Law, Philadelphia, 1953.

BERKİ, Şakir: "Roma'da Borçların Kaynakları”, Ankara Üniversitesi Hukuk Fakültesi Dergisi, Cilt:11, Say1:3, 1954, s. 378-413.

BİLGE, Burak: “Şantaj Suçu”, İstanbul Medipol Üniversitesi Hukuk Fakültesi Dergisi, Cilt: 6, Sayı: 1, 2019, s. 131-160.

DEMİİ̧̧, Bedia:“Eski Roma'nın Edebi Metinlerinde Bir Kavram Olarak Delictum'un AnlamıÜzerine Bir Değerlendirme", Roma Hukukundan Modern Hukuka Sorumluluk Sempozyumu, Cilt:14, Say1:4, 2008, s. 1-11.

DI MARZO, Salvatore: Roma Hukuku, İstanbul, 1959.

ERDOĞMUŞ, Belgin: Roma Borçlar Hukuku Dersleri, İstanbul, 2019.

GLOVER, Graham: "Metus in the Roman Law of Obligations", Fundamina: A Journal of Legal History, Say1:10, 2004, s. 31-58.

GÜNDAY, Onur: Cumhuriyet Dönemi Roma Toplumunda Kamu Suçları, Yargılamalar ve Ceza Uygulamaları, Ankara, 2019.

GÜNEŞ PESCHKE, Seldağ: Roma Hukukundan Günümüze Kişilik Haklarının Korunması (Iniuria), Ankara, 2014.

GÜRTEN, Kadir: “Roma'da Devlete Karşı İşlenen Bazı Suçlar ve Cezaları", Ankara Barosu Dergisi, Cilt: 75, Sayı: 3, 2017 (Suçlar), s. 5379.

GÜRTEN, Kadir: Roma Hukuku'nda Crimen Kavramı, Ankara, 2016 (Crimen).

HARRIES, Jill: Law and Crime in the Roman World, Cambridge, 2007.

HELMHOLZ, R.H.: "The Roman Law of Blackmail”, The Journal of Legal Studies, Vol: 30, No:1, 2001, s. 33-52.

HONIG, Richard: Roma Hukuku, İstanbul, 1938.

İPEK, Nurcan: Roma Hukukunda Gasp (Rapina), İstanbul, 2001 (Gasp). 
İPEK, Nurcan: “Roma Hukukunda Korkutma (Metus)”, Marmara Üniversitesi Hukuk Fakültesi Hukuk Araştırmaları Dergisi, Prof. Dr. Bülent Tahiroğlu'na Armağan, Cilt: 23, Sayı:3, 2017(Korkutma), s. 97-184.

KARADENİ ÇELEBİCAN, Özcan: Roma Hukuku, Ankara, 2020.

KARAKOCALI, Ahmet: Roma Hukukunda Hâkim ve Sorumluluğu, Ankara, 2011 (Hâkim).

KARAKOCALI, Ahmet: Roma Hukukunda ve Türk Hukukunda Korkutma (Metus), Ankara, 2016 (Korkutma).

KASER, Max: Roman Private Law, Çev.: Rolf Dannenbring, Pretoria, 1984.

KAYAK, Sevgi: “Roma Hukukunda Görevi Kötüye Kullanma Suçu: D. 48. 11 Metinlerinin Çevirisi ve Tahlili", Prof. Dr. Türkan Rado'nun Anısına Armağan, İstanbul, 2020, s. 737-768.

KOCA, Mahmut/ÜZÜLMEZ, İlhan: Türk Ceza Hukuku Özel Hükümler, Ankara, 2019.

KOSCHAKER, Paul/AYİTER, Kudret: Modern Özel Hukuka Giriş Olarak Roma Özel Hukukunun Ana Hatları, Ankara, 1977.

ÖNCÜL, Ayşe: Metus Kavramı ve Kurumlarının İncelenmesi, İstanbul, 2018.

ÖZBEK, Veli Özer/BACAKSIZ, Pınar/DOĞAN, Koray/TEPE, İlker: Türk Ceza Hukuku Özel Hükümler, Ankara, 2019.

ÖZER SARITAŞ, Duygu: Roma Ceza Hukuku'nda Daimî Ceza Mahkemeleri (Quaestiones Perpetuae), Bursa, 2020.

RADO, Türkan: Gaius Institutiones, İstanbul, 1953.

RADO, Türkan: Roma Hukuku Dersleri Borçlar Hukuku, İstanbul, 2016 (Borçlar).

RICHARDSON, J.S.: “The Purpose of the Lex Calpurnia de Repetundis", The Journal of Roman Studies, Vol: 77, 1987, s. 1-12.

SCHULZ, Fritz: “Humanitas”, Çev.: Diler Tamer Güven, Argumentum, Cilt: 3, Sayı: 30, 1993, s. 514-520.

SCHULZ, Fritz: Principles of Roman Law, Oxford, 1936.

SCHWARZ, Andreas B.: Roma Hukuku Dersleri, Cilt: 1, Çev.: Türkan Rado, İstanbul, 1963. 
SHERWIN-WHITE, A.N.: "The Lex Repetundarum and the Political Ideas of Gaius Gracchus", The Journal of Roman Studies, Vol: 72, 1982, s. 18-31.

SMITH, William: Dictionary of Greek and Roman Antiquities, London, 1853.

SOMER, Pervin: “Roma İmparatorluğunda Seçim Yolsuzlukları ve Ambitus", Marmara Üniversitesi Hukuk Fakültesi Hukuk Araştırmaları Dergisi, Prof. Dr. Bülent Tahiroğlu'na Armağan, Cilt: 23, Say1: 3, 2017, s. 33-54.

SÖĞÜTLÜ, Özlem: Roma Özel Hukuku, Ankara, 2020.

SÖĞÜTLÜ ERIŞGIIN, Özlem: Roma Hukuku'nda Haksız Fiil Benzerleri (Quasi Delicta), Ankara, 2002.

TAHİROĞLU, Bülent: Roma Borçlar Hukuku, İstanbul, 2020 (Borçlar).

TAHİROĞLU, Bülent: Roma Hukukunda Iniuria, İstanbul, 1969(Iniuria).

TANER, Fahri Gökçen: “Türk Ceza Hukukunda Şantaj Suçu”, Türkiye Barolar Birliği Dergisi, Sayı: 92, 2011, s. 118-156.

TEZCAN, Durmuş/ERDEM, Mustafa Ruhan/ÖNOK, Murat: Teorik ve Pratik Ceza Özel Hukuku, Ankara, 2019.

TÜRKOĞLU, Halide Gökçe:“Roma Hukukunda Humanitas ile Maiestas Populi Romani Arasındaki Bağlantı", Türkiye Barolar Birliği Dergisi, Sayı: 96, 2011 (Humanitas), s. 229-268.

TÜRKOĞLU, Halide Gökçe: Roma Hukukunda Suç ve Ceza, Ankara, 2017 (Suç ve Ceza).

TÜRKOĞLU ÖZDEMİ, Gökçe: “Roma Hukukunda Hâkimin Sorumluluğu", Marmara Üniversitesi Hukuk Fakültesi Hukuk Araştırmaları Dergisi, Cilt: 14, Sayı: 4, 2008 (Hâkimin Sorumluluğu), s. 275-302.

TÜRKOĞLU ÖZDEMIR, Gökçe: Roma Hukukunda Infamia (Şerefsizlik), Ankara, 2008 (Infamia).

TÜRKOĞLU ÖZDEMIR, Gökçe: “Roma Hukukunda Rüşveti Engellemeye Yönelik Düzenlemeler", Dokuz Eylül Üniversitesi Hukuk Fakültesi Dergisi, Cilt: 9, Özel Sayı, 2007 (Rüşvet), s. 1179-1213.

UÇARYILMAZ, Talya Şans/EMİROĞLU, Haluk: “Roma Hukukunda Haksız Fiil ve Suç İlişkisi Işı̆̆ında Tazminatın Cezalandırıcı Fonksiyonu", Ankara Üniversitesi Hukuk Fakültesi Dergisi, Cilt: 69, Sayı: 2, 2020, s. 835-868. 
UMUR, Ziya: Iustinianus Institutiones, İstanbul, 1968.

UMUR, Ziya: Roma Hukuku Ders Notları, İstanbul, 1999 (Ders Notları).

UMUR, Ziya: Roma Hukuku Lügatı, İstanbul, 1983 (Lügat).

WILINSKI, A.: “Roma Ceza Hukuku ve Ceza Usul Hukukuna Bir Kuşbakışı", Çev.: Belgin Erdoğmuş, Dicle Üniversitesi Hukuk Fakültesi Dergisi, Cilt: 1, Sayı: 1, 1983, s. 329-335.

ZIMMERMANN, Reinhard: The Law of Obligations: Roman Foundations of the Civilian Tradition, Cape Town, 1992. 